\title{
TEKNOLOJİK YETENEKLER, STRATEJİK ESNEKLİK ve ÜRÜN İNOVASYONU ARASINDAKİ İLISSKİLERİN TESPİTİ: TR63 BÖLGESİNDEKİ MOBİLYA İMALATÇILARI ÜZERİNE BİR
}

\author{
ARAŞTIRMA
}

Arif Selim EREN 1

Hüseyin ÇİÇEKLİOĞLU 2
Received Date (Başvuru Tarihi):

$2 / 09 / 2020$

Accepted Date (Kabul Tarihi):

$6 / 11 / 2020$

Published Date (Yayın Tarihi):
$\ddot{O Z Z}$

Anahtar Kelimeler:

Stretejik Esneklik,

Teknolojik Yetenek,

Ürün İnovasyonu,

TR 63 Bölgesi

JEL Kodlar:

M11, M15, O32
Günümüzde sürekli değişen pazar koşullarn işletmeleri müşterilerin istediği doğru ürünü üretmeye yönelik ürün inovasyonuna yöneltmektedir. İşletmler bunu elde edebilmek için stratejik esneklikle birlikte teknolojik yeteneklerini üst düzeyde tutmak zorundadır. Mobilya sektörü ise TR63 bölgesi (Hatay, Kahramanmaraş, Osmaniye) için katma değer üreten ve pazarlardaki gelişime kendini adapte etmeye çalışmaktadır. Bu çalışmada işletmelerin teknolojik yetenekleri ile birlikte stratejik esneklik düzeylerinin ve ürün inovasyonu algılarının ölçümü hedeflenmiştir. Ayrıca Zhou ve Wu (2010)'nun önerdiği modelin testi gerçekleştirilmiştir. Bu doğrultuda, Kahramanmaraş Sütçü İmam Üniversitesi Rektörlüğ̈̈ Sosyal ve Beşeri Bilimler Etik Kurulu tarafindan ilgili çalışma ve ankete yönelik verilen "Etik Kurul Belgesi" ile çalışma başlatılmıştır. Bu kapsamda öncelikle detaylı bir yazın taraması gerçekleştirilmiş ve önceki çalışmalardaki bilgiler ışı̆̆ııda kavramsal çerçeve oluşturulmuştur. Daha sonra yazındaki bilgiler ışı̆̆ında denenceler ortaya çıkarılmış ve sınanması için sektörde çalışan toplamda 179 kişiden veri toplanmıştır. Hipotezler regresyon modeli ile test edilmiş ve teknolojik yeteneklerin stratejik esneklikten yarı yarıya etkilendiği, stratejik esnekliğin de ürün inovasyonu alt boyutlarından üçte bir oranında etkilendiği belirlenmiştir. Sonuç olarak kavramların birbirini büyük ölçüde tamamladığı tespit edilmiştir. Böylece işletmelerin pazarlarda varlıklarını sürdürmek için ürün inovasyonuna ihtiyaç duydukları ve bunu teknolojik yeteneklerinin yanında stratejik esnekliği sağlayabilecek bir örgüt yapısı ile elde edebilecekleri ortaya konulmuştur. Çalışmanın son kısmında araştırmacılar ve uygulayıcılar için öneriler de sunulmaktadır.

\section{Keywords:

\footnotetext{
${ }^{1}$ Dr. Öğr. Üyesi, Kahramanmaraş Sütçü İmam Üniversitesi, arifselimeren@hotmail.com, https://orcid.org/0000-0001-7274-1113

2 Öğr. Gör. Dr., Mersin Üniversitesi, huseyinciceklioglu@gmail.com, https:// orcid.org/0000-0003-3922-6755
} 


\section{EXTENDED ABSTRACT}

\section{DETERMINING the RELATIONS BETWEEN TECHNOLOGICAL}

\section{CAPABILITIES, STRATEGIC FLEXIBILITY and PRODUCT INNOVATION: A RESEARCH On FURNITURE MANUFACTURERS IN TR63 REGION}

\section{LITERATURE}

\subsection{SUBJECT of the STUDY}

Today, businesses are experiencing intense competition at the international level with globalization (Fan et al., 2013: 187). It is stated that countries and businesses that take advantage of innovation in transition to the information society stand out compared to others (Kamasak et al., 2016: 126). As a result of the competition, it is seen that generic dimensions in competition priorities are always highlighted in the literature (Lei et al., 1996: 501). Thanks to these strategies, it is claimed that businesses can transform their production capability into higher profit margins by increasing the added value they create, and this can only be achieved with the effective use of the technological infrastructure used in production (Lew and Sinkovics, 2013: 13). Governments and business managers have problems with the long-term strategies they determine in such intense competitive environments, and this situation leads to the development of different applications related to the subsidy of the sector (Hit et al., 1998: 22). Based on this, it is observed that supporting the sectors according to the region that they belong to is an appropriate approach. TR63 Region is a classification applied by the Ministry of Development and includes Kahramanmaraş, Osmaniye and Hatay provinces. There is excellent potential in furniture manufacturing in this region, and they are in great demand both in domestic markets and in exports. The Eastern Mediterranean Development Agency (DOĞAKA) subsidies provided for the region in order to ensure the adaptation of the sector to technology have significantly improved the technological infrastructure of the enterprises.

\subsection{PURPOSE and IMPORTANCE of THE STUDY}

In this study, it was aimed to determine the relationships between the technological competencies, strategic flexibility and product innovation competencies of the furniture companies operating in the TR63 region.

\subsection{CONTRIBUTION of the STUDY to the LITERATURE}

When the results obtained from the study were examined, it was revealed that product innovation, supported by many studies in the conceptual framework, positively affected strategic flexibility, and strategic flexibility positively affected technological capabilities. Thus, it has been revealed that enterprises need product innovation in order to maintain their presence in the markets and can achieve this with an organizational structure that can provide strategic flexibility as well as technological capabilities.

\section{DESIGN and METHOD}

\subsection{RESEARCH TYPE}

The study utilizes a quantitative method, and the data were collected by questionnaire.

\subsection{DATA COLLECTION TECHNIQUE}

Questionnaire technique was used in the research. The scale used in the study conducted by Zhou and $\mathrm{Wu}$ (2010:547) in the creation of the research design was translated into Turkish and applied.

\subsection{QUANTITATIVE/QUALITATIVE ANALYSIS}

Firstly, the demographic characteristics of the sample were examined within the scope of the analysis. Then, their reliability was tested with the descriptive statistics and Cronbach Alpha values according to the dimensions in the questionnaire. In the next stage, variance tests were conducted to examine whether there were significant differences in the answers given to the questionnaire according to their demographic characteristics. Pearson's correlation, Exploratory Factor Analyses and Confirmatory Factor Analysis are conducted. At the last stage of the analysis, the mediating role of 
strategic flexibility between technological capabilities and product innovation, which is the primary purpose of the study, was tested with the regression model.

\subsection{RESEARCH HYPOTHESES}

$\boldsymbol{H}_{1}$ : Technological competencies of enterprises are positively affected by their strategic flexibility and product innovation capabilities.

$\mathbf{H}_{2}$ : Strategic flexibility is positively correlated with technological capabilities and product innovation.

$\boldsymbol{H}_{3}$ : Product innovation facilitates adaptation to the market and positively affects strategic flexibility and technological capabilities.

\section{RESULTS and DISCUSSION}

\subsection{HYPOTHESIS TEST RESULTS}

The dimensions of product innovation affect strategic flexibility positively. It also significantly affects technological capabilities in strategic flexibility. When the impact values are analyzed, it is observed that the market size is adequate at close to one-third levels in other product innovation variables. It has also been shown that technological turbulence, together with the change in utility, affects the strategic flexibility by one-tenth to one-third of discovery. Along with these, one of the most important findings is that strategic flexibility can explain almost half of the technological capabilities. These findings show that the model of Zhou and $\mathrm{Wu}$ (2010:547) was realized in those who manufacture furniture in the TR 63 region. Thus, it is seen that there are significant relationships in the dimensions of change in utility and technological turbulence. As a result of the findings, research hypotheses were accepted.

\subsection{RESULTS of the STUDY}

With the analysis of the data obtained from 176 people within the scope of the research, it is observed that the model is also confirmed in this context. Based on the findings, it is observed that the results of many studies in the literature are supported. Li et al. (2017: 471), Li et al. (2010: 300), CabelloMedina et al. (2006: 80), Bock et al. (2010: 1) and Beraha et al. (2018: 129) when strategic flexibility rises, the product reports that its innovation has increased. The same result was obtained in the current study. Based on this, it is understood that the flexible distribution of resources will provide a significant benefit. Bierly et al. (1996: 368) state that there is a need for scales that can be used for quantitative measurement of strategic flexibility, and it is observed that the scale we adapted in our study gave reliable and valid results.

\subsection{SUGGESTIONS BASED on the RESULTS}

When all these discussions are evaluated together, it is thought that enterprises should implement human resources policies in a way to maximize themselves in terms of technological capabilities and make an effort to create and retain a qualified workforce. It is also hoped that their efforts to review and refine existing processes continually will also benefit them. As the last word, it is hoped that a user study has been carried out by reminding that only countries' economies can develop with products with high added value and that policies that will create qualified workforce are needed to achieve this.

\subsection{LIMITATIONS of the STUDY}

The limitation of this study is that it is limited to 176 individuals working in companies in the TR63 region. 


\section{GİRIŞ}

Günümüzde işletmeler küreselleşme ile birlikte uluslararası düzeyde rekabeti yoğun biçimde yaşamaktadır (Fan ve diğerleri, 2013: 187). Bilgi toplumuna geçişte inovasyonun avantajını kullanan ülkelerin ve işletmelerin diğerlerine göre daha öne çıktı̆̆ı ifade edilmektedir (Kamasak ve diğerleri, 2016: 126). Yaşanan rekabetin bir sonucu olarak rekabet önceliklerinde jenerik boyutların yazında sürekli öne çıkarıldığ1 görülmektedir (Lei ve diğerleri, 1996: 501). Bu stratejiler sayesinde işletmelerin ortaya çıkardığı katma değeri artırarak üretimden gelen kabiliyetini daha yüksek kâr marjina dönüştürebildiği ve bunun ancak üretimde kullanılan teknolojik altyapının etkin kullanımı ile gerçekleşebileceği iddia edilmektedir (Lew ve Sinkovics, 2013: 13).

İmalat teknolojilerindeki gelişmeler sayesinde işletmeler artık daha esnek biçimde müşterilerin taleplerini karşılarken diğer taraftan da pazardaki değişikliklere daha çabuk ayak uydurabilmektedir (Beraha ve diğerleri, 2018: 129). Böylece işletme yöneticilerinin esneklik ile etkinlik arasında bir tercih yapmaları beklenmektedir (Kortmann ve diğerleri, 2014: 475). Ancak bunu gerçekleştirirken değişime karşı yaşadıkları örgütsel direnç performanslarını düşürmekte ve teknolojik yeterliklerin örgütsel dinamiklere etkilerinin incelenmesinde çok az çalışma olduğu bildirilmektedir (Bierly ve diğerleri, 1996: 368). Diğer taraftan hem teknolojik kabiliyetlerin hem de inovasyonla ilgili yeterliklerin stratejik esneklikle ilişkili olduğu dile getirilmektedir (Bock ve diğerleri, 2012: 279). Değişen rekabet şartlarına ayak uydurmaları için Chen ve diğerleri (2017: 10) stratejik esnekliğin kaynakların dağıtımındaki esneklik ile birlikte çevresel koşulların her an yeniden değerlendirilmesi gerektiğini savunmaktadır.

Böylece işletmelerin var olan süreçlerini pazardan gelen talepler karşısında değiştirme çabaları yeterli olmamaktadır. Nitekim bu tür savunma stratejisini benimseyen işletmelerin sadece pazar fiyatı artık oluşmuş olan ürünlerin üretimine yoğunlaştıkları gözlenmektedir. Ancak Fan ve diğerleri (2013: 187) stratejik esneklik açısından yüksek rekabetin olduğu alanlarda reaktif stratejilerin de işletmenin kendisini koruyabilmesi için yeterli olabileceğini savunmaktadır. Buna karşın, Hervas-Oliver ve diğerleri (2014: 873), inovasyonla pazarın kaymağını alabilecek 
ürünler ortaya koymanın yoğun rekabetçi piyasalarda daha etkili sonuçlar ortaya koyabileceğini iddia etmektedir. Li ve diğerlerine (2017: 471) göre sektörün paradigmasını değiştirecek kadar radikal inovasyonun işletmenin operasyonlarından daha fazla kar elde etmesini sağlayabileceği gibi başarısızlık durumunda kötü sonuçlar ortaya çıkarabilmektedir. Ayrıca Jaija ve diğerleri (2017: 1064) ürün inovasyonu ile ilgili hususların genelde tedarik zinciri ile ilgili boyutların olduğunu ve işletmenin yeni ürünler ortaya koyabilmesi için bahsedilen bütün unsurların uyumlu bir şekilde çalışması gerektiğini belirtmektedir.

Hükümetler ve işletme yöneticileri bahsettiğimiz bu tür yoğun rekabet ortamlarında belirledikleri stratejilerin uzun soluklu olmasında problemler yaşamakta ve bu durum sektörün sübvansiyonu ile ilgili farklı uygulamaların gelişmesine yol açmaktadır (Hitt, Keats ve DeMarie, 1998: 22). Ayrıca küresel belirsizlikler işletmelerin kendileri için bir yol haritası belirlemelerini zorlaştırmaktadır (Singh, Oberoi ve Ajuha, 2013: 1442; Tamayo-Torres, Ruiz-Moreno ve Verdú, 2010: 1120). Buradan hareketle bölgesel olarak sektörlerin desteklenmesinin uygun bir yaklaşım olduğu gözlenmektedir. TR63 Bölgesi, Kalkınma Bakanlığ1 tarafından uygulanan bir sınıflandırma olup Kahramanmaraş, Osmaniye ve Hatay illerini kapsamaktadır. Bu bölgede mobilya imalatı ile ilgili büyük bir potansiyel bulunmakta ve gerek iç pazarlar gerekse de ihracatta önemli talep görmektedirler. Sektörün teknolojiye uyumunun sağlanması için bölge ile ilgili sunulan Doğu Akdeniz Kalkınma Ajansı (DOĞAKA) sübvansiyonları işletmelerin teknolojik altyapılarını önemli ölçüde geliştirmiştir. Ancak işletmelerin teknoloji ediniminden en fazla faydayı görebilmeleri için örgütsel iklimini de bu hususta uyumlaştırması gerekmektedir. Buradan hareketle mevcut çalışmada bölgede faaliyet gösteren mobilya işletmelerinin teknolojik yeterlikleri, stratejik esneklikleri ve ürün inovasyonu yeterlikleriyle ilgili algıları arasındaki ilişkilerin belirlenmesi amaçlanmıştır.

Bu hususta Branzei ve Vertinsky (2006: 75) özellikle bölgedeki işletmelerde olduğu gibi Küçük ve Orta Büyüklükteki İşletmelerin (KOBİ) teknoloji ediniminden başarı sağlayabilmeleri için örgütsel stratejilerini de teknolojiyle uyumlu hale getirmesi gerektiğini savunmaktadır. Ayrıca Cabello-Medina ve diğerleri (2006: 80) örgütsel süreçlerin uyumlaştırılabilmesi için rekabet konusunun sürekli gündemde 
tutulması gerektiğini ve işletmelerin kendilerini diğerlerinin performansına göre kıyaslamalarının avantajlar sağlayabileceğini ortaya koymaktadır. Bu hususta tekerleğin yeniden icadının gerekli olmadığını ve teknoloji yönetimi ve inovasyonla ilgili gelişmelerin takip edilmesi sayesinde kümülatif bir bilgi birikiminin farklı ampirik içerikle sınanmasının yazına katkı sağlayabileceği rapor edilmektedir (Lyytinen ve diğerleri, 2016: 47). Hâlihazırda gerçekleştirilen çalışma kapsamında üç ilden toplanan verilerle Kahramanmaraş, Osmaniye ve Hatay illerindeki firmaların tabakalı örnekleme yöntemleriyle kıyaslanması da sağlanacaktır.

Bu bilgilerden hareketle mevcut çalışmada TR63 Bölgesinde faaliyet gösteren mobilya imalatçısı firmalarda teknolojik yetenekler, stratejik esneklik ve ürün inovasyonu arasındaki ilişkilerin belirlenmesi sağlanacaktır. Bu kapsamda işletmelerin sayıları illerin sanayi ve ticaret odalarından elde edilmiştir. $\mathrm{Bu}$ işletmelerden tabakalı örneklemle Osmaniye'den 17, Kahramanmaraş'tan 49 ve Hatay'dan da 110 işletmeye ulaşılarak toplamda 176 işletmeden veriler toplanmıştır. Elde edilen veriler bir set haline getirilerek SPSS 22.0 paket programı kullanılarak analiz edilmiştir. Analiz kapsamında ilk önce örneklemin demografik özellikleri incelenmiştir. Daha sonra anketteki boyutlara göre tanımsal istatistikleri ve Cronbach Alfa değerleri ile de güvenirlikleri test edilmiştir. Bir sonraki aşamada demografik özelliklerine göre ankete verilen cevaplarda anlamlı farkların olup olmadığının incelenmesi için varyans testleri gerçekleştirilmiştir. Boyutlar arasındaki ilişkilerin tespiti için Pearson korelasyonu ve boyutların veride ayrışıp ayrışmadığının kontrol edilebilmesi için de Keşif Amaçlı Faktör Analizi ve Doğrulayıcı Faktör Analizi yapılmıştır. Analizin son aşamasında ise regresyon modeli ile çalışmanın temel amacı olan ürün inovasyonu ile teknolojik yetenekler arasında stratejik esnekliğin aracı rolü test edilmiştir.

Çalışmadan elde edilen sonuçlar incelendiğinde kavramsal çerçevede pek çok çalışmayla desteklenen ürün inovasyonunun stratejik esnekliği olumlu etkilediği, stratejik esnekliğin de teknolojik yetenekleri pozitif yönde etkilediği ortaya konulmuştur. Araştırmanın sonuç kısmında işletme yöneticilerinin ve araştırmacıların uygulayabilecekleri öneriler de sunulmaktadır. 


\section{YAZIN TARAMASI}

Araştırmanın gerçekleştirilebilmesi için yöntem ve kavramsal çerçevenin oluşturulmasıyla ilgili konu hakkında yazında önceden yapılmış olan çalışmaların incelenmesi gerçekleştirilmiştir. Çalışma neticesinde elde edilen bulgular aşağıdaki şekildedir.

Beraha, Bingöl, Özkan-Canbolat ve Szczygiel (2018: 129) ürün inovasyonunda stratejik esnekliğin nasıl sağlanabileceğini ele aldığı çalışmasında bulanık mantık kullanarak insan kaynaklarındaki esnekliğin önemli etkileri olabileceğini bulmuştur.

Bierly ve diğerleri (1996: 368) eczacılık endüstrisi bağlamında teknolojik öğrenme, stratejik esneklik ve yeni ürün geliştirmeyi ele aldıkları araştırmalarında 1977 ila 1991 arasındaki verileri inceleyerek öğrenmenin uzun soluklu ve pek çok kavramın etkili olduğu bir süreç olduğunu vurgulamıştır.

Bock ve diğerleri (2010: 1) ise iş modeli inovasyonu ve stratejik esnekliği resmi ve gayri resmi yollardan inceledikleri çalışmalarında 556 şirketin üst yönetiminden elde ettiği verileri incelemiştir. Sonuç olarak inovasyon odaklı örgüt kültürünün stratejik esnekliği sağladığı ortaya konulmuştur. Benzer biçimde Bock ve diğerleri (2012: 279) iş modellerinde stratejik esnekliği ve inovasyonu inceledikleri çalışmalarında örgütsel boyutların dinamik becerilere sahip insan kaynakları ile biçimlendirilmesi gerektiğini savunmaktadır.

Branzei ve Vertinsky (2006: 75) KOBİlerde ürün inovasyonu yeterliğinde stratejik yol haritalarını incelemektedir. Bu kapsamda pazarla ilgili odağın yanında süreçlerin de ihmal edilmemesi gerektiği ortaya konulmaktadır. Yine KOBI'ler bağlamında yapılan bir çalışmayla Hervas-Oliver ve diğerleri (2014: 873) süreç inovasyonu stratejilerinin örgütsel inovasyon ve performansa etkilerini incelemektedir. İspanya bağlamında yapılan çalışmada maliyetlerin düşürülmesi, esnekliğin sağlanması, kapasite geliştirme, satışlardaki değişimin takibinde yapılan yanlışların ortadan kaldırılması ve ürün odaklı süreçlerin işletilmesi gibi stratejiler benimsenmesinin olumlu etkilerinin olabileceği düşünülmektedir.

Cabello-Medina ve diğerleri (2006: 80) ise İspanya bağlamında 124 işletmeden elde ettikleri verileri kullanarak inovasyon, stratejik esneklik ve bunların örgüt 
kültürüne yansımalarını incelemiştir. Araştırma sonunda örgütsel dinamiklerin ürün inovasyonu ile birlikte stratejik esnekliğin boyutları üzerinde etkili olduğu ifade edilmektedir.

Chen ve diğerleri (2017: 10) Çin Halk Cumhuriyeti bağlamında yaptığ1 araştırmada bilgi iletişim teknolojilerinin stratejik esnekliği ne yönlerde geliştirdiğini araştırmıştır. 148 işletmeden toplanan verilerle gerçekleştirilen çalışma neticesinde elde edilen bulgular incelendiğinde bilgi iletişim teknolojileri sayesinde işletmelerin en fazla bilgi edinme ve pazarın nabzını tutma hususlarında faydalandıkları gözlenmektedir.

Fan ve diğerleri (2013: 187) ise çevresel değişimle birlikte şekillenen inovasyon süreçlerinde stratejik esneklikteki reaktif ve proaktif uygulamaları incelemektedir. Toplamda 180 işletmeden Çin bağlamında toplanan verilerin analizi ile birlikte hem reaktif hem de proaktif stratejik esnekliğin inovasyon üzerinde olumlu etki yaptığ1 ortaya konulmuştur. Ayrıca yüksek teknolojik türbülansın olduğu alanlarda işletme yöneticilerinin reaktif stratejik esnekliğe dikkat etmesi gerektiği vurgulanmaktadır.

Hit ve diğerleri (1998: 22) rekabetçiliğin günümüzde nasıl algılandı̆̆ını belirlemeye yönelik yapmış oldukları çalışmada stratejik esnekliğin etki edebileceği unsurlar üzerine odaklanmaktadırlar. Sonuç olarak ulaştıkları bulgular incelendiğinde artık pazarın yönlendirdiği bir işletmecilik kültürünün egemen olacağ1 ve işletmelerin bu konuda ayakta kalmak için esnekliği en üst düzeylerde sağlaması gerektiği görülmektedir.

Jaija ve diğerleri (2017: 1064) kaynak temelli bir yaklaşımla inovasyon stratejisi, ürün inovasyonu ve iş performansı arasındaki ilişkileri incelemiştir. Çalışmadan elde edilen bulgular müşterilerin üretim süreçlerine dâhil edilmesinin ve uluslararası pazarların nabzının tutulmasının daha etkin süreçler elde edilmesine yardımcı olduğunu göstermektedir.

Kamasak ve diğerleri (2016: 126) ise stratejik esnekliğin bilgi ve inovasyon yönetimindeki önemini inceleyen bir araştırma yürütmüştür. 187 firmadan toplanan verilerin analizi ile stratejik esnekliğin bilgi yönetiminden çok inovasyon yönetimi becerileri ile ilişkili olduğunu ortaya koymaktadır. 
Kortmann ve diğerleri (2014: 475) örgütsel ustalık bağlamında stratejik esneklik ve operasyonel etkinlik arasındaki ilişkileri incelediği çalışmalarında kaynak temelli değerlendirmelerin günümüz işletmeciliği ile tam olarak uyuşmadığını belirtmektedir. Çalışmadan elde edilen sonuçlar incelendiğinde üretimde etkinliğin sağlanması için örgütsel yeteneklerin de geliştirilmesi gerektiğine işaret etmektedir.

Lei ve diğgerleri (1996: 501) örgütsel yapı ile stratejik esneklikte ileri imalat teknolojilerinin etkilerini incelemektedir. Teknolojik gelişmeler sayesinde işletmelerin esnekliğinin üretim boyutunda önemli ölçüde ileri noktalara taşındığı, ancak örgütün buna hazır olmaması durumunda kısıtlar yaşanabileceği öngörülmektedir.

Lew ve Sinkovics (2013: 13) ise işletmelerin küreselleşme ile birlikte yapmak zorunda kaldıkları stratejik iş birliklerinde ürün inovasyonu ve rekabet öncelikleri konularını ele almaktadır. Çalışmadan ortaya çıkan bulgular incelendiğinde işletmelerin oluşturdukları ağların pazarın nabzının tutulmasında önemli etkiler ortaya çıkardığını ve pazarların yönlendirdiği bir iklimin egemen olduğu anlaşılmaktadır.

Li ve diğerleri (2010: 300) 607 kişiden elde ettiği verileri kullanarak stratejik esnekliğin ürün inovasyonuna etkilerini incelemektedir. Çalışmanın sonuçları incelendiğinde stratejik esnekliğin sağlanması ile ürün inovasyonunun daha kolay bir şekilde yapılabildiği gözlenmektedir.

Li ve diğerleri (2017: 471) ise kaynakların yeniden yapılandırılmasının stratejik esneklik ve inovasyon üzerindeki etkilerini inceleyen bir araştırma yürütmüştür. Toplamda 508 kişiden elde edilen verilerin analiziyle stratejik esnekliğin artmasının inovasyon performansını yükselttiği bulunmuştur.

Lyytinen ve diğerleri (2016: 47) dijitalleşme ile birlikte inovasyon süreçlerinin ürüne yansımalarını inceledikleri çalışmalarında bu teknolojiler sayesinde daha etkin bir iletişim ağının ortaya çıktığını belirtmektedirler. Ayrıca işletmelerin ve çalışanların oluşturdukları ağların daha etkin biçimde inovasyon süreçlerini gerçekleştirmeyi sağladı̆̆ı ortaya konulmaktadır.

Rajala ve diğerleri (2012: 1368) ise açık kaynaklı yazılımlar için ortaya koydukları bir iş modelinde stratejik esneklik ve açı inovasyon konularını ele 
almaktadır. Çalışmadan ortaya çıkan sonuçlar incelendiğinde inovasyon süreçlerinde açık bir iklimin sağlanmasının ortaya çıkan nihai ürünlerin pazardaki karşılı̆̆ının artmasına neden olduğu görülmektedir.

Sanchez ve Mahoney (1996: 63) ise modüler ürün tasarımının esneklik ve bilgi yönetimi konularındaki etkilerini ürün ve örgüt tasarımı bağlamında incelemektedir. Çalışma neticesinde ortaya koydukları bulgular incelendiğinde yeni teknolojilerin ediniminin esnekliği artıracağını ve bununla birlikte verimliliğin de yükseleceği görülmektedir. Ancak örgütsel süreçlerdeki değişim dinamiklerine dikkat edilmesi gerektiği anlaşılmaktadır. Benzer biçimde Worren ve diğerleri (2002: 1123) de modüler üretim sistemlerinin stratejik esneklik ve işletme performansı üzerindeki etkilerini incelemektedir. Çalışmadan elde edilen sonuçlar örgütsel kabiliyetlerin de bu hususları destekleyecek şekilde yapılandırılması gerektiğini savunmaktadır.

Santos-Vijande ve diğerleri (2012: 1079) ise örgütsel öğrenme bağlamında esneklik, rekabet önceliği ve performans boyutlarının etkileşimini incelemektedir. 181 kişiden toplanan verilerin analiziyle ortaya çıkarılan yapısal eşitlik modeli incelendiğinde öğrenmenin düzeyi arttıkça esneklik alg1sı da yükselmektedir. Bununla birlikte rekabet önceliği algıları da artış sergilemektedir. Netice itibariyle işletme kültürünün öğrenen örgütler şeklinde yapılandırılmasının önemli avantajlar elde edilmesini sağlayacağ1 görülmektedir.

Schneider ve Spieth (2014: 1440009) iş modeli inovasyonu ve stratejik esnekliği deneysel bir çalışma ile karşımıza çıkarmaktadır. Yapılan uygulama neticesinde inovasyon düzeyi arttıkça stratejik esneklik algısının da yükseldiği gözlenmektedir.

Singh ve diğerleri (2013: 1442) imalat işletmelerinde stratejik esnekliğin yönetiminde önemli olan becerileri konu edinen bir araştırma yürütmüştür. 102 işletmeden elde edilen veriler ışığında insan kaynakları, inovasyon, teknolojik, iş birliği ile ilgili ve geliştirme becerilerinin önemli olduğu ortaya konulmaktadır.

Tamayo-Torres ve diğerleri (2010: 1120) gerçekçi iş koşulları ile stratejik esneklik arasında inovasyon kabiliyetlerinin etkilerini inceleyen bir araştırma yapmıştır. Sonuç olarak işletme yöneticilerinin ileride olabilecekleri tam olarak 
kestirmesinin mümkün olmadığı, bunun üstesinden gelmek içinde örgütü her koşula hazır hale getirmeleri gerektiği ifade edilmektedir.

Tutar ve diğerleri (2015: 709) pazar performansı ile inovasyon kabiliyetleri arasındaki stratejik unsurları inceledikleri çalışmalarında stratejinin ürünlerin pazar performansının belirlenmesinde önemli etkileri olduğunu ortaya koymaktadır.

Verdu-Jover ve diğerleri (2005: 131) ise esneklik ile inovasyon arasındaki uyumu inceleyen bir çalışma yapmıştır. Toplamda 417 işletmeden elde edilen verilerin analiziyle inovasyonun düzeyi arttıkça esnekliğin de geliştiği bulunmuştur.

Yalçınkaya ve diğerleri (2007: 63) inovasyonda önemli boyutlar olan keşif ve faydada inovasyonun ürün inovasyonu ve piyasa performansı üzerine etkilerini inceleyen bir çalışma gerçekleştirmiştir. Çalışma kapsamında 111 firmadan veri toplanmış ve faydada değişimin ürünlerin piyasadaki performansı üzerine daha büyük fayda sağladığı tespit edilmiştir.

Zhang (2006: 84) ise bilgi iletişim teknolojilerinin çevresel dinamizm ve işletme performansı ile stratejik esneklik üzerindeki katkılarını ele alan bir çalışma yapmıştır. Araştırma sonunda bilgi ve iletişim teknolojileri sayesinde firmaların daha esnek bir yapıya daha hızlı şekilde uyumlaşarak çevresel etkileri azaltabildikleri bulunmuştur.

Son olarak Zhou ve Wu (2010: 547) mevcut çalışmanın da temelini oluşturan bir araştırmayla teknolojik yeterlikler, stratejik esneklik ve ürün inovasyonu arasındaki ilişkileri incelemiştir. Sonuç olarak teknolojik yeterliği olan firmaların stratejik esneklik ve ürün inovasyonu boyutlarında daha olumlu bir yapıya kavuştuğu gösterilmektedir. Ayrıca teknolojik yeterlikler bakımından üstün olanların keşifte dağıtım noktasında daha etkin bir performans sergiledikleri belirlenmiştir.

Konu ile ilgili çalışmalar genel olarak incelendiğinde stratejik esneklik, ürün inovasyonu ve teknolojik yeterliklerin birbirini tamamlayan ögeler olduğu anlaşılmaktadır. Araştırmanın bundan sonraki bölümlerinde ise teorik çerçevenin sunumu ile birlikte hipotezlerin geliştirilmesi sağlanacaktır. 


\section{TEORİ ve HIPOTEZLER}

Teknolojik gelişmeler işletmecilik kültürünün her zaman yeniden yapılanmasına neden olmaktadır. Ayrıca pazarların dinamik yapısı işletmelerin stratejik karar almada sürekli olarak esnekliği gözetlemelerini gerektirmektedir. Bunun bir sonucu olarak da ürün inovasyonunun üretim süreçlerinde dinamik bir halde tutulması gerektiği gözlenmektedir. Araştırmanın bu kısmında teknolojik yeterliklerle ürün inovasyonu arasındaki ilişkide stratejik esnekliğin rolünü anlamak adına kavramsal bilgiler sunulacaktır.

\subsection{Teknolojik Yetenekler}

İşletmelerin günümüz koşullarında hayatta kalmaları pazardaki paylarını genişleterek daha fazla üretim kabiliyeti elde etmeye dayanmaktadır. Böylece otomasyon gibi sistemlerle maliyetlerini aşağı çekerek bütün süreçlerini daha kolay bir şekilde biçimlendirmelerinin mümkün olacağı iddia edilmektedir (Chen ve diğerleri, 2017: 10). Bu kapsamda Hit ve diğerleri (1998: 22) internet bağlamında gerçekleşen gelişmelere dikkat çekerek işletmeciliğin teknoloji yönetim becerileri ile rekabet edebilmeyi gerektirdiğini vurgulamaktadır. Hatta Tutar ve diğerleri (2015: 709) teknoloji sayesinde fiyatların ve maliyetlerin aşağı düşürülebileceğini, bu sayede ortaya çıkan maliyet avantajının da işletmelerin rekabetçiliğini göstereceğini iddia etmektedir. Böylece diğer alanlardan ziyade üretim ve bilgi yönetimini kolaylaştıracak teknolojilerin geliştirilmesi gerektiği öngörülmektedir.

Teknolojik altyapının yanında örgütsel süreçlerin teknoloji edinimine hazır hale getirilmesiyle işletmelerin fayda elde edebileceği değerlendirilmektedir (Kamasak ve diğerleri, 2016: 126). Yalçınkaya ve diğerleri (2007: 63) işletmelerin başarılı olabilmeleri için stratejik esneklik boyutunda diğerlerine nazaran üstün bir performans sergilemeleri gerektiğini göstermektedir. Böylece işletmelerin edinim ile birlikte ortaya çıkacak karmaşayı engelleme ve edinimden maksimum faydayı elde etme üzerinde yoğunlaşabilecekleri düşünülmektedir. Bu kapsamda görüşlerini dile getiren Kortmann ve diğerleri (2014: 475), örgütsel yapının günümüz koşullarına ayak uydurabilmek için esnek halde tutulması gerektiğini ve bunun yanında kaynakların dağıtımında dengeli bir politikaya ihtiyaç olduğunu ve böylece de etkinliğin 
artırılabileceğini savunmaktadır. Benzer biçimde Lyytinen ve diğerleri (2016: 47) günümüzde dijitalleşme ile birlikte bireylerin ve işletmelerin etkileşim kabiliyetlerinin arttığını ve bunun gereği olarak daha yüksek rekabet normlarına ulaşıldığını vurgulamaktadır. Bu kapsamda etkinliği yakalamak için edinimin sosyal boyutları içinde değerlendirilmesinin faydalı sonuçlar elde edilmesini sağlayacağı düşünülmektedir. Son olarak Zhou ve Wu (2010: 547) işletmelerin pazarda tutunabilmesinin yeterli olmayacağını ve piyasaları yönlendirebilmek için yenilikçi ürünlerle rekabet avantajı kazanabileceklerini iddia etmektedir.

Bütün bu bilgiler 1şı̆̆ında değerlendirme yapacak olursak günümüzde hem teknolojik gelişmeler hem de pazarlardaki arz ve talep dinamik bir yap1 sergilemektedir. Netice itibariyle işletmelerin bu pazarlarda hayatta kalmaları ve rekabet edebilmeleri için yeni ürün geliştirme süreçlerine ihtiyaç duyacakları görülmektedir. Bunu gerçekleştirmek için yeni süreçler ve sistemlerin edinimi gerekmektedir. Elde edilecek yeni sistemin etkin şekilde kullanımı da öğrenen örgütler biçiminde tasarlanmış örgütsel yapı ile mümkündür. Dolayısıyla teknolojik yetenekler salt edinimi değil, aynı zamanda uyumlaştırma ve koordinasyonu da içermek durumundadır. Buradan hareket ederek aşağıdaki hipotez geliştirilmiştir;

$\boldsymbol{H}_{1}$ : Issletmelerin teknolojik yeterlikleri stratejik esneklikleri ve ürün inovasyonu kabiliyetlerinden pozitif etkilenmektedir.

$\mathrm{Bu}$ kapsamda işletmelerin geliştirmeleri gereken birtakım beceriler bulunmaktadır. Aşağıda bunların teker teker incelenmesinin konunun aktarımı açısından fayda sağlayacağı düşünülmüştür.

\subsubsection{Belirleme}

Teknoloji yönetiminde önemli bir boyut olarak karşımıza çıkan belirleme aşamasında işletmenin uluslararası alanda hedeflediği pazar payına ulaşabilmesi için gerekli makine ve teçhizatın belirlenmesi gerekmektedir. İşletme yöneticileri açısından zor bir karar verme süreci olarak önümüze çıkan belirleme aşamasında işletmenin yapacağı harcamanın ne kadar süre içinde geri dönüşünün sağlanacağı ve bunun finansal karşılığı da hesaplanmalıdır. Dinamik bir şekilde gerçekleşen bir süreç olduğu için de sürekli olarak yeni üretim ve otomasyon teknolojilerinin takibi gerekmektedir 
(Cabello-Medina ve diğerleri, 2006: 80). Chen ve diğerleri (2017: 10) günümüz koşullarında iş yapabilmek ve yeni pazarlar elde edebilmenin önemli ölçüde üretimde kullanılan teknolojiye bağlı olduğunu belirtmektedir. Aynı zamanda Hit ve diğerleri (1998: 22) çevresel koşullara ayak uydurabilmek için işletmelerin gelişmiş üretim teknolojileri kullanmalarının önemini vurgulamaktadır. Benzer biçimde Worren ve diğerleri (2002: 1123) de modüler biçimde esnek üretim sistemlerinin işletmelerin rekabetçiliğinde önemli avantajlar sağladığını göstermektedir.

$\mathrm{Bu}$ bilgiler bir bütün olarak incelendiğinde işletmelerin belirleme süreçlerinde önemli bir unsur olarak teknoloji yönetimini sağlamaları ve bunu yaparken de kaynaklarını etkin kullanmak adına belirleme süreçlerini pazarlardaki ve üretim teknolojilerindeki gelişmelere göre uyarlamaları gerektiği görülmektedir.

\subsubsection{Seçme}

Belirleme sürecinde mevcut ve potansiyel seçeneklerin ortaya konulmasından sonra işletmenin en düşük maliyetle ve uyum çabasıyla en yüksek verimliliği elde edeceği sistemin seçimi gerçekleştirilmektedir. Seçme aşamasında işletmenin üretmeyi düşündüğü ürün yelpazesi göze alınarak sadece gerekli olanların seçiminin sağlanması gerektiği belirtilmektedir (Hit ve diğerleri, 1998: 22). Ayrıca Kortmann ve diğerleri (2014: 475) işletmelerin teknolojileri seçiminde en yüksek verimlilik ve en kısa geri dönüş sürelerini gözden geçirmesi gerektiğini dile getirmektedir. Böylece edinimden beklenen faydaların stratejik esnekliği de etkileyebileceği düşünülmektedir. Bunlarla birlikte Tutar ve diğerleri (2015: 709) işletmenin altyap1 gereksinimlerini değerlendirerek kendisi için en uygun olan seçeneği belirlemesinin avantaj sağlayacağını iddia etmektedir.

Sonuç olarak seçme aşamasında işletmenin bugünkü ihtiyaçlarının yanında gelecekteki gereksinimlerini de göz önünde bulundurarak işgücü ve enerji ihtiyacı, eğitim ve oryantasyon olanakları, finansman kolaylığı ve diğer ekipmanlarla uyum potansiyeli gibi unsurları göz önünde bulundurarak seçmeyi gerçekleştirmesi gerektiği anlaşılmaktadır. 


\subsubsection{Edinme}

Teknoloji yönetiminin bir sonraki aşaması olan edinmede işletmenin belirleme ve seçme aşamasındaki aldığı kararı uygulaması gerekmektedir. Bu kapsamda Branzei ve Vertinsky (2006: 75) işletmenin önceliklerinin belirlenmiş olmasının işletmenin ihtiyaçlarının planlanmasında önemli avantajlar elde etmesini sağlayacağını göstermektedir. Benzer biçimde Cabello-Medina ve diğerleri (2006: 80) de edinme gerçekleştirmeden önce örgütsel ve altyapı ile ilgili hazırlıkların tamamlanmış olmasını ve yeni teknolojinin getireceği karmaşanın ancak etkin hazırlanmış bir edinim planı ile mümkün olacağını iddia etmektedir. Bunlara ek olarak Hervas-Oliver ve diğerleri (2014: 873) edinimin büyük ölçüde yönetsel becerilerle olumsuz yönlerinin ortadan kaldırılabileceğini ve tepe yönetiminin destek verdiği projelerde daha başarılı olma ihtimalinin olduğunu göstermektedir. Bu sayede işletmenin ileri imalat teknolojisindeki başarısının stratejik esnekliğe ve teknolojik yeterliklere bağlı olarak gerçekleşeceği de ifade edilmektedir (Hit ve diğerleri, 1998: 22). Ancak edinimden beklenen faydaların gerçekleşebilmesi için işletmenin kendi finansal yükümlülüklerini yerine getirerek projenin aksamasının önüne geçmesi gerektiği de belirtilmektedir (Li ve diğerleri, 2017: 471).

$\mathrm{Bu}$ bilgiler bir arada değerlendirildiğinde işletmelerin edinimden fayda görebilmeleri için altyapılarının hazır halde olması gerektiği, tepe yönetiminin desteğinin önemli bir ölçüt olduğu, finansal yükümlülüklerin yerine getirilmesinin edinim planının başarılı olması için önem arz ettiği ve işletmenin stratejik esnekliğinin önemli etkiler ortaya koyabileceği değerlendirilmektedir.

\subsubsection{Kullanma}

İşletmenin ihtiyacı olan teknolojinin belirlenmesi, seçimi ve ediniminden sonra amacı doğrultusunda kullanılması teknoloji yönetim sürecinde önemli bir aşama olarak karşımıza çıkmaktadır. Bu noktada ileri imalat teknolojileri esnek üretim kabiliyetleri olduğu için işletmelerin teknolojiyi edindikten sonra da başka amaçlarda kullanmak üzere dönüştürmelerine de olanak sağlamaktadır (Branzei ve Vertinsky, 2006: 75). Teknolojinin amacı doğrultusunda kullanımının ürün mimarisi açısından faydalar da elde edilmesini sağlayabileceği değerlendirilmektedir. $\mathrm{Bu}$ sayede 
işletmenin üretimde esneklik kabiliyetinin de gelişebileceği vurgulanmaktadır (Hit ve diğerleri, 1998: 22). Netice itibariyle kullanma boyutunda işletmenin hem operasyonel kabiliyeti artmakta hem de örgütsel süreçlerinin daha düzenli bir hale bürünmesi sağlanabilmektedir (Lei ve diğerleri, 1996: 501).

Teknolojilerin kullanımı ile ilgili olarak elde edilen bilgiler bir bütün halinde incelendiğinde amacı doğrultusunda kullanılması, getirdiği esnekliği ürün tasarımına da yansitabilmesi ve böylece de daha fazla hareket olanağ1 sağladığı gözlenmektedir. İşletmenin bu avantajı ürünlerine yansıtmasının da müşteri taleplerine daha fazla cevap verebilecek ürünlerle rekabetçiliğinin artmasını sağlama potansiyeline sahip olduğu görülmektedir.

\subsubsection{Sonlandirma}

Teknoloji yönetimi sistem yaklaşımı içinde sürekli devam eden bir olgu halindedir. Dolayısıyla bu döngü içinde makine ve ekipmanların yanında yönetsel süreçler de elbet bir gün sona ermek durumunda kalmaktadır. İşletmenin makine ve ekipmandan ekonomik ömrünü tamamladıktan sonra daha iyisi ile eskisini değiştirmesi gerekmektedir. Bu kapsamda yapılacak olan yeni edinim bir önceki süreçlerdeki örgütsel öğrenmenin üzerine inşa edilmelidir. Böylece sonraki edinimler teknoloji transferinden, asimilasyona, asimilasyondan da Ar-Ge'ye doğru yol alınmasını sağlamaktadır (Branzei ve Vertinsky, 2006: 75). Bu sayede işletmelerin ileri imalat teknolojileri ile birlikte stratejik esnekliğinin de artmasına neden olmaktadır (Hit ve diğerleri, 1998: 22). Sonuç olarak teknolojik kabiliyetlerin işletmelerin örgütsel ve işlevsel kabiliyetlerini artırma potansiyeline sahip olarak görülmektedir (Yalçınkaya ve diğerleri, 2007: 63).

Buradan elde edilen bilgiler bir arada değerlendirilecek olursa teknoloji yönetiminde ekonomik ömrünü tamamlamayan makine ve ekipmanın yenilenmesinin işletmeye zarar getirebileceği görülmektedir. Ancak günümüz koşullarında makine ve ekipmanların ekonomik ömrü kısa olduğu gibi yeni gelişen teknoloji ile birlikte çok çabuk şekilde demode olabilmektedir. Netice itibariyle işletmenin karlılığını koruyacak şekilde teknoloji edinimi gerçekleştirmesi ve bunu yaparken de teknolojiden maksimum düzeyde faydalanacak şekilde yeteneklerini gözden 
geçirerek örgütsel yapısını da buna hazır hale getirmesi gerektiği görülmektedir. Böylece teknolojik kabiliyetlerle ilgili kavramsal çerçeve oluşturulmuştur. Bir sonraki bölümde ise stratejik esneklikle ilgili bilgiler sunulacaktır.

\subsection{Stratejik Esneklik}

Teknolojik bakımdan altyapı gereksinimlerini tamamlayan ve bunu kullanmaya yönelik etkinlik temelli bir örgütsel öğrenme haline gelen işletmelerin rekabette öne çıkacağı ve yeni ürün geliştirme ile birlikte pazarın gereksinimlerini karşılayacak şekilde adaptasyonu sağlayabileceği değerlendirilmektedir (Beraha ve diğerleri, 2018: 129). Bock ve diğerlerine (2010: 1) göre örgütler stratejik olarak esnekliği sağladıklarında çevresel etkileri avantajına çevirebilecek kabiliyetlere kavuşmaktadır.

Kavram olarak değerlendirildiğinde stratejik esneklik örgütün çevresel değişimlere kendisini adapte edebilme kabiliyeti olarak tanımlanmaktadır ( $\mathrm{Li}$, Li, Wang ve Ma, 2017: 471; Chen, Wang, Nevo, Benitez ve Kou, 2017: 10; Schneider ve Spieth, 2014: 1440009; Tamayo-Torres ve diğerleri, 2010: 1120; Verdu-Jover, LlorensMontes ve Garcia-Morales, 2005: 131; Bock, Opsahl ve George, 2010:1). Bunun yanında Cabello-Medina ve diğerleri (2006: 80) stratejik esnekliğin geleneksel yapıda inovasyon temelli olarak değişimi beraberinde getirdiğini dile getirmektedir. Ayrıca Fan ve diğerleri (2013: 187) stratejik esneklikle birlikte işletmenin performansında olumlu değişim kaydedilebildiğini ve reaktif tarzda bir esneklik yerine pro-aktif bir yaklaşımın daha etkili sonuçlar ortaya koyabileceğini göstermektedir. Ayrıca stratejik esneklik sayesinde işletmenin bilgi akışını kontrol etme avantajı sağlayarak pro-aktif şekilde rekabetçiliğini artırabileceği de savunulmaktadır (Lyytinen ve diğerleri, 2016: 47).

Bunlara ek olarak stratejik esneklikle işletmenin rekabette çok ihtiyaç duyacağ acil durumlarda karar verebilme esnekliği ile uzun dönemde elde edilmesi planlanan amaçların uyarlanması olanağı elde edilebileceği de ifade edilmektedir. Bunu sağlamak için de inovatif bir örgüt kültürüne ihtiyaç duyulacağı dile getirilmektedir (Hit ve diğerleri, 1998: 22). Böylece işletmenin kaynaklarını etkin bir şekilde dağıtma 
kabiliyeti kazanarak pazardaki değişime kendisini daha iyi bir şekilde adapte edebileceği vurgulanmaktadır (Kamasak ve diğerleri, 2016: 126).

Öteki taraftan işletmelerin stratejik esneklik kabiliyetlerinin kısıtlı kaldığ1 anlarda operasyonel etkinliğinde zayıflama kaydedilebileceği şeklinde uyarıların da olduğu gözlenmektedir (Kortmann ve diğerleri, 2014: 475). Bunun yanı sıra Tutar ve diğerleri (2015: 709) işletmelerin performans göstergeleri arasında pazara, teknolojiye ve girişimciliğe uyumun öneminden bahsederken stratejik esneklik olmadığında bahsedilen boyutlarda da ilerleme kaydetmenin güçleşeceğini dile getirmektedir. Dolayısıyla stratejik esnekliğin firmanın çevresel etkileri elimine edebilmek için kullandığı ve değişime hızlı bir şekilde cevap verebilme kabiliyeti kazanmasına neden olduğu anlaşılmaktadır (Li ve diğerleri, 2010: 300). Bunun yanında stratejik esneklikle birlikte işletmenin üretimde daha hızlı hareket edebileceği ve buna bağlı olarak da üretimde etkinliğin artacağı ve bunun düzeyinin işletmenin rekabetçiliğini de belirleyebileceği dile getirilmektedir (Singh ve diğerleri, 2013: 1442). Esnekliğin derecesi ile ilgili olarak Santos-Vijande ve diğerleri (2012: 1079) işletmenin geçmişte ne kadar tecrübesi varsa o kadar esnek kararlar alabilme yeteneğine kavuştuğunu iddia etmektedir. Dolayısıyla işletmeler ne kadar iş bitirme odaklı çalışırsa o kadar fazla deneyim biriktirmiş sayılmaktadır. Son olarak Zhou ve Wu (2010: 547) stratejik esnekliğin rutinin dışına çıkarak üretimde ve diğer işletme fonksiyonlarında daha fazla karar seçeneği ortaya koyduğunu dile getirmektedir.

Bütün bu bilgiler ışı̆̆ında değerlendirildiğinde stratejik esnekliğin ürün inovasyonu ve teknolojik yeteneklerle ilgili olduğu düşünülmektedir. Buradan hareketle aşağıdaki hipotez geliştirilmiştir;

$\mathbf{H}_{2}$ : Stratejik esneklik teknolojik yeteneklerle ürün inovasyonu ile olumlu biçimde ilişkilidir.

Kavramsal çerçevenin gerçekleştirilecek olan ampirik çalışmada daha iyi sunulabilmesi için stratejik esnekliğin alt boyutlarıyla ilgili bilgilerin de sunumunun faydalı olacağı değerlendirilmektedir. Bu nedenle çalışmanın ilerleyen kısımlarında pazarlama, ürün çeşitliliğii, kaynakların dağıtımı ve dağıtım kanallarında esneklik hakkında bilgilerin sunumu planlanmıştır. 


\subsubsection{Pazarlama Yöntemlerinde Esneklik}

İşletmenin bütün fonksiyonlarında olduğu gibi pazarlama boyutunda da işletmenin değişen pazar koşullarına göre kendisini uyarlaması önerilmektedir. Bu kapsamda gelişen teknoloji ile birlikte pazarlama olanaklarının da çeşitlendiği bildirilmektedir (Beraha ve diğerleri, 2018: 129). Pazara adaptasyon ve yeni pazarlama olanaklarının kullanılması üretimde elde edilen çıktıların daha geniş alanlarda talep görmesini sağlamaktadır. Ancak Bierly ve diğerlerinin (1996: 368) de ifade ettiği üzere pazarlamada esnekliğin sağlanması müşterilerin ürün imajı ve bağlılıklarını olumsuz etkileyerek rekabetten dolayı pazardaki payın düşmesine de neden olabilmektedir. Dolayısıyla işletmelerin ürün ve hizmetlerinin rekabetçiliğini önde tutan tutundurma politikaları izlemesi önerilmektedir.

Etkin bir pazarlama stratejisi uygulayabilmek için pazardan gelen bilgilerin iyi bir biçimde yönetilmesi gerekmektedir (Chen ve diğerleri, 2017: 10). Pazarın nabzını tutarak gerektiğinde ürününde geliştirme ve inovasyona giden işletmelerin performanslarının daha yüksek olduğu belirtilmektedir (Fan ve diğerleri, 2013: 187). Buradan hareketle işletmenin pazarlama stratejisinin belirlenmesinde stratejik esnekliğin ön planda tutulması gerektiği anlaşılmaktadır. Ayrıca stratejik esneklik sayesinde işletmenin yeni yapılanmalarda yerini alarak rekabet öncesinde iş birliği olanakları elde edebileceği de dile getirilmektedir. Bu kapsamda uluslararası pazarın olanaklarının farkına varılması ve kullanılması önerilmektedir (Hit ve diğerleri, 1998: 22). Aynı zamanda işletmenin pazarlama yöntemlerinde esneklik elde edebilmesi için ilk olarak kaynaklarını tedarik ettiği ağla etkileşim içinde pazarlama karmasını belirlemesi de önemle vurgulanmaktadır (Li ve diğerleri, 2010: 300). Bu kapsamda Lyytinen ve diğerleri (2016: 47) dijitalleşmenin getirdiği avantajları kullanarak daha küçük harcamalarla daha büyük pazarlama olanaklarının elde edilebileceğini vurgulamaktadır. Bahsedilen olanaklara kavuşabilmek için de çok fazla paydaşla etkileşim halinde bulunulması gerektiği ve bunun çözümünün de yine teknoloji odaklı biçimde gerçekleştirilebileceği gösterilmektedir (Rajala ve diğerleri, 2012: 1368). Sonuç olarak pazarlama yöntemlerinin esnetilmesine yönelik gerçekleştirilecek çabaların işletmenin performansını artıracağı ve bu sayede operasyonel etkinliğinin de artış sergileyeceği öngörülmektedir (Singh ve diğerleri, 2013: 1442). Müşterinin taleplerini 
karşılamak üzere geliştirilen ürün ve hizmetlerin beklenilen faydayı sağlayabilmesi için de pazar odaklı hareket edilmesi gerektiği belirtilmektedir (Tutar ve diğerleri, 2015: 709).

Yukarıda bahsedilen bilgiler bir arada değerlendirildiğinde pazarlamanın bütün işletme süreçlerinde önemli bir husus olduğunu göstermektedir. Ayrıca dijitalleşme ile birlikte daha fazla etkileşim olanağının sağlanması ile daha geniş bir pazarlama planı ortaya koyulabileceği ve bunun maliyetinin teknoloji kullanımı sayesinde daha düşük maliyetlerle gerçekleştirilebileceği gösterilmektedir. Netice itibariyle işletmenin pazarlama yöntemlerini uyarlama kabiliyeti piyasadaki değişime adapte olabilme kabiliyetini göstermektedir.

\subsection{2. Ürün Çeşitliliği ve Tasarımında Esneklik}

Günümüz koşullarında işletmelerin ürettikleri mal ve hizmetlerde çeşitlilik sağlamaları pazardaki paylarını korumaları ve genişletmeleri için önem arz etmektedir. Her geçen gün çeşitlenen müşteri taleplerini karşılayabilmek için işletmelerin üretimde esnekliğe kavuşmaları önerilmektedir. Bu durumda işletme yöneticilerinin üretimde esnekliği sağlayabilecek teknolojik altyapıyı kurmaları gerekmektedir. Ayrıca esnek üretim sistemlerinin gereği olarak hızlı karar vermede çalışanları bilinçlendirmeli ve onları gerektiğinde delege edebilmeleri ve sonuç odaklı olarak sistemin sürekli gözden geçirilmesini sağlamaları önerilmektedir (Beraha ve diğerleri, 2018: 129). Benzer biçimde Bierly ve diğerleri (1996: 368) de üretimde etkinliğin korunması için esnekliğe ihtiyaç duyulduğunu ve bunu en ekonomik biçimde sağlamak için süreçlerde, tesislerde ve ürün gamında gerektiğinde değişiklik yapabilmenin önemli olduğunu vurgulamaktadır. Bu durumu destekler nitelikte Branzei ve Vertinsky (2006: 75) de süreçlerin dinamik ve inovasyon odaklı biçimde yapılandırılması gerektiğini savunmaktadır.

Üretim sistemlerinin esnek hale getirilebilmesi için yüksek teknoloji kullanan altyapını kurulması önemli görülmektedir (Hit ve diğerleri, 1998: 22). Bu kapsamda Sanchez ve Mahoney (1996: 63) modüler ürün tasarımı ile işlevselliğin önde tutulduğu bir örgüt kültürünün ortaya çıkarılmasını önermektedir. Singh ve diğerleri (2013: 1442) ise finansal olarak esnekliğin sağlanması halinde işletmenin üretim ve inovasyon 
konusunda mesafe kaydedebileceğine işaret etmektedir. Bu kapsamda girişimcilik temelli olarak hareket etmenin işletmenin faydasına sonuçlar ortaya çıkarabileceği değerlendirilmektedir (Tutar ve diğerleri, 2015: 709).

Ürün çeşitliliği ve tasarımıyla ilgili yukarıdaki bilgiler bir arada değerlendirilecek olursa sadece teknolojik altyapının hazır hale getirilmesinin yeterli olmayacağ1 gözlenmektedir. Örgütsel yapının da öğrenen örgütler bağlamında göz önünde bulundurulmasının önemli faydaları olacağı görülmektedir. Netice itibariyle hem finansal hem de tedarikle ilgili kısıtları göz önünde bulundurarak ve paydaşları süreçlerin içine çekme yoluyla piyasanın ihtiyaç duyacağı doğru ürün ve hizmetlerin ortaya çıkarılabileceği değerlendirilmektedir.

\subsubsection{Kaynakların Dağılımında Esneklik}

Tıpkı bir organizma gibi işletmelerde kaynakların bir yöne fazla dağıtılması toplam sağlığı tehlikeye atabilecek sonuçlar ortaya çıkarabilmektedir. Bu nedenle kaynakların etkin biçimde dağıtılmış olması işletmenin avantajlar kazanmasını sağlamaktadır. Dengeli biçimde büyüme eğilimi göstereceği için de işletmenin sürdürülebilirliği açısından faydalar elde edilmesini sağlayabileceği düşünülmektedir. İşletmelerin üretim süreçlerinde ihtiyaç duyduğu kaynaklar incelendiğinde insan kaynakları, sermaye, girişim ve hammadde ile enerji gibi girdilerin olduğu gözlenmektedir. Bunların yeterli miktarda bulunması üretimi mümkün hale getirebileceği gibi eksik olması da ket vurmayla sonuçlanabilmektedir. İşletmenin beklenen faydayı sağlayabilmesi için bu kaynakların kimi zaman birbirini yedekleyebilecek şekilde tasarlanması gerekmektedir. Ancak bu hususla ilgili yazında fazla bulgunun olmadığı dile getirilmektedir (Li ve diğerleri, 2017: 471).

Oysa Singh ve diğerleri (2013: 1442), Hit ve diğerleri (1998: 22) ve Beraha ve diğerleri (2018: 129) insan kaynaklarında birbirini yedekleyebilecek şekilde bir yapılanmanın olumlu etkiler yapabileceğini ve üretimin sürdürülebilirliği açısından fayda sağlayacağını göstermektedir. Bierly ve diğerleri (1996: 368) ise finansal kaynaklara vurgu yaparak ekonomik açıdan finansal istikrarı sağlamış bir işletmenin her türlü edinimi rakiplerine oranla daha rahat gerçekleştirebileceğini rapor etmektedir. Benzer biçimde yeni örgütlenmeler içinde olma ve işletmeyi birbirini 
tamamlayan kümeler olarak görmenin de etkin sonuçlar ortaya çıkarabileceği dile getirilmektedir (Kamasak ve diğerleri, 2016: 126; Hit ve diğgerleri, 1998: 22).

Bunların yanında işletmede inovatif bir örgüt kültürünün hâkim olması ve buna bağlı olarak bireylere kendilerini geliştirme olanaklarının verilmesinin de kaynakların yönetiminde etkin bir strateji olabileceği değerlendirilmektedir (Worren ve diğgerleri, 2002: 1123; Kortmann ve diğerleri, 2014: 475). Başarı elde edilebilmesi için kaynakların tahsisi kadar koordinasyonunun da önemli olduğu ve bunun da inovasyon ve işletme performansı üzerinde olumlu etkilerinin olabileceği de dile getirilmektedir (Li ve diğerleri, 2010: 300).

$\mathrm{Bu}$ bilgiler 1şı̆̆ında incelendiğinde kaynakların yönetimi ve paylaşımının işletme içi dengelerin gözetilmesi için önemli olduğu ve örgütsel adalet açısından da olumlu sonuçlar ortaya çıkarabileceği değerlendirilmektedir. Asgari düzeyde kaynakların sağlanması ile üretim mümkün olabileceği için bunların birbirini yedekleyebilme kabiliyetinin olması beklenmektedir. Ancak finansal esneklik olduğu sürece bunun gerçekleştirilebileceği düşünülmektedir.

\subsubsection{Dağıtım Kanallarında Esneklik}

Küresel ve yerel bağlamda gerçekleşen gelişmeler işletmelerin dağıtım kanallarını sürekli yenilemelerine neden olmaktadır. Ürün ve hizmetlerin ortaya çıkarılabilmesi için çok kapsamlı bir tedarik ağının kurulması ülkelerin birbiriyle daha fazla etkileşime girmelerine neden olmaktadır (Beraha ve diğerleri, 2018: 129). Üretim sistemleriyle ilgili teknoloji transferinin yoğun biçimde gerçekleşmesi neticesinde artık neredeyse dünyanın her yerinde üretim kapasiteleri rapor edilmektedir (Bierly ve diğerleri, 1996: 368). İşletmelerin bu süreçlerden kendilerine avantajlar çıkarabilmeleri için esnekliği sağlayan birtakım kabiliyetler geliştirmeleri gerektiğine işaret edilmektedir (Hit ve diğgerleri, 1998: 22).

Bu kabiliyetlerden birisi olarak dağıtım kanallarındaki esneklik âtıl kapasitenin oluşmasına engel olmaktadır. Tedarik zincirlerinin üretim sistemlerine doğrudan katılımının sağlanması sayesinde dağıtım kanallarının da zenginleşebileceği vurgulanmaktadır (Jaija ve diğerleri, 2017: 1064). Kortmann ve diğerlerinin (2014: 475) de üzerinde durduğu şekliyle stratejik esnekliğin sağlanması işletmelerin farklı 
arayışlar içine girmesine neden olmaktadır. Böylece tek bir kanal üzerinde sıkışmış ve pazar payını genişletmekte güçlük yaşayan işletmecilikten uluslar ötesi işler yapabilen bir ekonomik görünüm elde edilmiştir (Li ve diğerleri, 2017: 471). Bu kapsamda Lyytinen ve diğerleri (2016: 47) işletmelerin piyasalarda etkinliğini etkileşim içinde oldukları ağların etkinliği ile doğru orantılı göstermektedir. Böylece Singh ve diğerlerinin (2013: 1442) de ifade ettiği üzere daha fazla bilgi paylaşımı gerçekleştirmek mümkün olmaktadır.

Yukarıdaki bilgiler ışı̆̆ında bir değerlendirme yapacak olursak dağıtım ağlarındaki esneklik işletmenin dar piyasalarda sıkışmasının önüne geçmektedir. Ancak küresel bağlamda rekabetçiliği ve yeterli finansal desteği olmayan işletmeler için dağıtım kanallarının genişlemesi problemlerin artmasına neden olabilmektedir. Bu duruma çare olarak da işletmenin iş yaptığı paydaşlarla etkin bir a ğ oluşturması gerekmektedir.

\section{3. Ürün İnovasyonu}

Teknolojik yetenekler ve stratejik esnekliğin boyutlarının açıklanmasından sonra araştırmamızın bu bölümünde ürün inovasyonu ile ilgili kavramsal çerçeve sunularak boyutlarının açıklanması sağlanacaktır. İşletmelerin pazarda her gün değişen müşteri isteklerini karşılayabilmeleri için ürünlerinde değişiklik yapmaları gerekmektedir. Bu bağlamda maliyetlerin ürün fiyatında ve miktarındaki etkisi kadar müşteri isteklerini karşılama oranını artırmak üzere inovasyonu kullanma da önem arz etmektedir. Yazında bu kavramla ilgili bilgiler incelendiğinde inovasyonun radikalliğinin pazarda oluşturabileceği etki ile doğru orantılı olduğu ifade edilmektedir. Ancak radikalliğin herhangi bir ölçütünün de olmadığı kabul edilmektedir (Cabello-Medina ve diğerleri, 2006: 80).

Diğer taraftan Fan ve diğerleri (2013: 187) pazarda müşterilerin talepleri doğrultusunda ürünlerde inovasyonun çevresel etkenlerle zayıflayan rekabetçiliği dengeleyebileceğini öngörmektedir. $\mathrm{Bu}$ sayede yeni ürünlerin pazarlarda tutundurulması kadar eski ürünlerin de pazardaki paylarının artırılmasının sağlanabileceği düşünülmektedir. Böylece işletmenin rekabetçiliğinin sürdürülebilir hale gelebileceği savunulmaktadır (Li ve diğerleri, 2010: 300). Ürünlerin niteliğinin 
değiştirilmesinde teknolojik unsurlarının artırılması gibi uygulamalara gidilebileceği gibi azaltmanın da maliyetler bağlamında inovasyonu sağlayacağı değerlendirilmektedir (Hervas-Oliver ve diğerleri, 2014: 873). Sonuç olarak üründe inovasyonun işletmenin performansını artırıcı bir etkisinin olduğu varsayılmaktadır (Jaija ve diğgerleri, 2017: 1064). Dolayısıyla Ar-Ge süreçlerinin sürekli devam ettirilmesi önerilmektedir. Bu kapsamda işletmelerin stratejik ortaklıklar kurarak pazarda sürekli varlıklarını devam ettirme konusunda çaba harcamaları gerektiği vurgulanmaktadır (Lew ve Sinkovics, 2013: 13). Ayrıca firmaların inovasyon kabiliyetlerini artırmaları için de iş ortakları ile etkin iletişim halinde olması gerektiği gösterilmektedir. Böylece yüksek teknolojik içeriği olan ürünlerin inovatif dokunuşlarla katma değerinin artırılabileceği savunulmaktadır (Verdu-Jover ve diğerleri, 2005: 131).

Ancak ürün inovasyonu ile birlikte ürünlerin üretiminde ve kullanımında artan teknolojik yetenek ihtiyacı karşılanmadığında işletmenin beklediği faydayı elde edemeyeceği değerlendirilmektedir. $\mathrm{Bu}$ nedenle teknolojik niteliği artıran bir inovasyon yapıldığında işletmenin hem çalışanlarına hem de müşterilerine eğitim desteği sağlayarak kendilerini yenileme olanağı sunması gerektiği belirtilmektedir (Tamayo-Torres ve diğerleri, 2010: 1120). Sonuç olarak inovasyonun işletmenin bütün fonksiyonları üzerinde olumlu etkiler ortaya koyabileceği ve çevresel baskılara gögüus gerebilmesi için de gerekli olduğu belirtilmektedir (Zhou ve Wu, 2010: 547).

Ürün inovasyonu ile ilgili genel bilgiler bir arada değerlendirildiğinde işletmelerin çevresel şokları karşılama kabiliyetlerini artırdığı gözlenmektedir. Ancak örgütsel yapı ile birlikte teknolojik yetenekler bakımından hazırlıkları yapılmadan gerçekleştirildiğinde pazardaki karşılığının beklenenden daha düşük düzeylerde kalacağı anlaşılmaktadır. Buradan hareketle aşağıdaki hipotez geliştirilmiştir;

H3: Ürün inovasyonu pazara adaptasyonu kolaylaştırdığı gibi stratejik esneklik ve teknolojik yetenekler üzerinde de olumlu etkiler yapmaktadır.

Kavramsal çerçevenin tamamlanması için faydada, keşifte, teknolojik türbülansta ve pazara adaptasyon konusunda da değişimin açıklanmasının faydalı olacağ1 değerlendirilmiştir. Dolayısıyla çalışmanın ilerleyen bölümlerinde bu konuların açıklanması sağlanacaktır. 


\subsubsection{Faydada Değişim}

İşletmelerin temel hedefi insanların ihtiyaçlarını karşılamak üzerine kurgulanmıştır. Bu kapsamda ürettikleri mal ve hizmetlerin insanların yaşamında katma değer oluşturması ve faydayı gözetmesi beklenmektedir. Branzei ve Vertinsky (2006: 75) bu kapsamda gerçekleştirmiş olduğu değerlendirmede bireylerin fayda görmediklerini düşündükleri mal ve hizmetlerin pazarlanmasında daha zorlu süreçler yaşandığını belirtmektedir. Öte yandan Hervas-Oliver ve diğerleri (2014: 873) ürünlerin fayda algısının artırılmasının maliyetlerin kabullenilmesinde etkin rol oynayarak işletmenin karlılığını yükseltebileceğini iddia etmektedir. Bu sayede süreçlerinde esnek davranma kabiliyeti elde edilerek ürünlerin inovasyonunun daha etkin biçimde gerçekleştirilebileceği öngörülmektedir. Dolayısıyla arzulanan esneklik ile gerçekleşen esneklik arasındaki makasın da daralabileceği iddia edilmektedir (Verdu-Jover ve diğerleri, 2005: 131). Son olarak Yalçınkaya ve diğerleri (2007: 63) ürünlerin fayda algısının artırılması için teknolojik özelliklerinin artırılması gerektiğine vurgu yapmaktadır.

Bu konu ile ilgili elde edilen bilgiler bir arada değerlendirildiğinde müşterinin kendisine fayda sağlayacağını düşündüğü ürünleri satın almada daha istekli davranacağı görülmektedir. Ayrıca üründe fayda algısını artıracak şekilde teknolojik özellikler eklemenin de müşteri devamlılığını sağlamada avantaj elde edilmesini sağlayacağı düşünülmektedir.

\subsubsection{Keşifte Değişim}

İşletmelerin Ar-Ge ve inovasyonla ilgili süreçleri sürekli daha iyi üretim süreçlerine ulaşmak üzerine yoğunlaşmaktadır. Sonuç olarak gerçekleştirilen keşifler sürekli sistemin mükemmelleştirilmesi üzerine kurgulanmaktadır. Müşteri taleplerinden hareketle başlayan keşif süreçlerinde ortaya çıkan ürünlerin piyasadaki performansının daha üstün olacağı dile getirilmektedir (Cabello-Medina ve diğerleri, 2006: 80). Ancak Hervas-Oliver ve diğerlerinin (2014: 873) de ifade ettiği üzere sadece üretim yöntemlerinde teknoloji edinimine ve geliştirilmesine dayanan keşfin işletmenin potansiyelinin altında kalmasına neden olabileceği değerlendirilmektedir. $\mathrm{Bu}$ nedenle teknolojik olduğu kadar teknolojik olmayan yönetsel süreçlerde de 
değişime ihtiyaç duyulacağ1 görülmektedir. Böylece stratejik esnekliğin ürün inovasyonunda keşif boyutunda etkili olacağı anlaşılmaktadır.

Diğer taraftan Lei ve diğerleri (1996: 501) ileri imalat teknolojileri sayesinde işletmede çalışanların makine ve ekipmanlara asıl işleri gerçekleştirme potansiyeli elde ettikleri için keşif için ayıracakları zaman ve enerjiyi iyi değerlendirmeleri durumunda pazarlama konusunda da yeni keşifler gerçekleştirebileceklerini iddia etmektedir. Bu sayede işletmenin piyasadaki değişime daha erken tepki verebileceği de gösterilmektedir. Benzer biçimde Rajala ve diğerleri (2012: 1368) açık inovasyonla uğraşarak imalat yükünün teknolojiye yüklenmesi ve insan kaynaklarının inovatif süreçlerde daha fazla yer almasının önermektedir. Yine bu bilgiyi destekler biçimde Yalçınkaya ve diğerleri (2007: 63) de işletmenin ana odağının inovasyona dönüştürülmesi için keşfin gerekliliğini, keşfin de yapılması için araştırma gayreti olması gerektiğini savunmaktadır.

Keşifle ilgili yazındaki bilgiler bir arada incelendiğinde işletmenin temel fonksiyonu olan üretimi gerçekleştirebilmesi için insan kaynaklarının motivasyonunu inovasyona kaydırması, iş yükünün de teknolojiye devredilerek daha yüksek katma değere ulaşılması önerildiği gözlenmektedir. Ancak bunu gerçekleştirebilmek için işletmede nitelikli işgücüne ihtiyaç olacağı ve üretimin gerçekleştirilmesi için kullanılan makine ve ekipmanların da otomasyonla insana ihtiyaçlarının azaltılması gerektiği görülmektedir.

\subsubsection{Teknolojik Türbülans}

İşletmelerin teknolojiye uyumu tarih boyunca rekabetçilikleri için önemli avantajlar kazanmalarına neden olmuştur (Bock ve diğerleri, 2012: 279). Pazarda gerçekleştirecekleri etki açısından da işletmenin teknoloji kullanım ve üretim düzeyinin önemli farklar ortaya koymalarını sağlamaktadır (Cabello-Medina ve diğerleri, 2006: 80). Fan ve diğerlerine (2013: 187) göre stratejik esnekliğin temel amac1 teknolojik gelişmelere ayak uydurabilecek eylemleri gerçekleştirmektir. Dolayısıyla teknolojik türbülans ne kadar yüksek düzeyde gerçekleşirse işletmenin üretimde esnekliği ve yönetim süreçleri de bir o kadar hızlı değişim içine girebilmektedir. 
Gerek pazarlama gerekse diğer işletme fonksiyonlarında hızla yaşanan değişim sonucunda işletmelerin teknolojiye ayak uydurmaları artık günümüzde yüksek katma değer ortaya çıkarmamaktadır. Bu nedende gelecekteki teknolojik ihtiyaçları şimdiden belirleyerek süreçlerini ona göre yapılandıran işletmelerin daha yüksek başarı elde edebilecekleri gösterilmektedir (Hervas-Oliver ve diğerleri, 2014: 873). Bu süreçlerde bilgiyi doğru yönetebilenlerin öne çıkacağı da vurgulanmaktadır. Bilgiye ulaşım için de stratejik ortaklıklar kurmanın işletmeye fayda sağlayabileceği gösterilmektedir (Lew ve Sinkovics, 2013: 13). Böylece yüksek türbülansın yaşandığg ortamlarda işletmenin karar verebilmesi için dinamik birtakım kabiliyetlerinin olması gerektiği belirtilmektedir (Kamasak ve diğerleri, 2016: 126). Bu bağlamda işletmenin artan çevresel baskıları karşılayabilmesi için stratejik esnekliğe ve teknolojik yeteneklere ihtiyaç duyabileceği değerlendirilmektedir (Lei ve diğerleri, 1996: 501).

Santos-Vijande ve diğerlerine (2012: 1079) göre teknolojik türbülansın yüksek olduğu zamanlarda işletmelerin çevresel baskılara maruz kalması çok yüksek bir ihtimaldir. Buna göre işletmenin kendisini koruyacak ve uyumlaştıracak dinamik yeteneklerinin olması gerekmektedir. Benzer biçimde Tutar ve diğerleri (2015: 709) de işletmenin yeteneklerini gözden geçirmesi gerektiğini ve gerekli olduğu hallerde çok kolay biçimde örgütleyebileceği bir ağı oluşturmasının faydalı olacağını dile getirmektedir.

Netice itibariyle teknolojik türbülans her gün yeni gelişen teknoloji ile birlikte artarak devam edecek bir husus olarak karşımıza çıkmaktadır. İşletmelerin her gün yeni teknolojiyi adapte etme gibi bir olanağı olmadığı için rekabetçilik bakımından geriye düştüklerini anladıkları zamanda kadar edinim planlaması gerçekleştirmemeleri gerekmektedir. Ancak geleceğin teknolojik ihtiyaçlarını şimdiden öngören ve bunu sağlayan işletmelerin de daha başarılı olacakları düşünülmektedir.

\subsubsection{Pazara Adaptasyon}

Hayatın her alanında olduğu gibi ekonomi de dinamik bir yapıdadır. Böylece işletmeler pazarda paylarını korumak ve genişletmek için daha etkin işletmecilik süreçlerine ihtiyaç duymaktadır. Pazardaki paylarını artırmak için yeni pazarın 
gereksinimlerini sürekli analiz etme ihtiyacı olduğu gibi mevcut paylarını korumak adına da piyasalardaki değişimi gözeterek ürünlerinde inovasyona gitme ihtiyacı hissetmektedirler. Bu kapsamda Cabello-Medina ve diğerleri (2006: 80) piyasanın ihtiyaç duyduğu doğru ürünü belirlemiş olmanın işletmenin stratejik kararlarından en önemlilerinden birisi olduğunu vurgulamaktadır. Benzer biçimde Fan ve diğerleri (2013: 187) de piyasanın ihtiyaç duyduğu ürünlerin elde edilebilmesi için teknolojik yeteneklerin geliştirilmesi gerektiğine işaret etmektedir. Bu bilgileri destekler nitelikte pazarın ihtiyaçlarının işletmenin örgütsel yapısını da değiştirmeye mecbur bıraktığı gösterilmektedir (Hervas-Oliver ve diğerleri, 2014: 873).

Diğer taraftan Hit ve diğerleri (1998: 22) küreselleşmenin dünya çapında iş birliklerine işletmeleri ittiğine vurgu yaparak uluslararası pazarların ihtiyaçlarını karşılamak için işletmelerin etki alanlarındaki iş ortaklarıyla stratejik iş birliği içinde olmalarını vurgulamaktadır. Ayrıca Lew ve Sinkovics (2013: 13) bu iş birliklerinin işletmelerin inovasyonla ilgili ihtiyaçlarını belirlemede avantaj elde etmelerini sağlayacağını dile getirmektedir.

Pazardaki değişime ürün inovasyonu ile ayak uydurma ile ilgili bilgiler bir arada incelendiğinde dinamik bir yapıya karşı stabil bir organizasyon yapısının başarı getirmeyeceği anlaşılmaktadır. Böylece işletmenin kendisini pazarın isteklerine göre müşterilerini de üretim ve ürün tasarımı süreçlerine dâhil ederek daha etkin bir yapıya bürünmesi önerilmektedir. Netice itibariyle çalışmanın kavramsal çerçevesi tamamlanmış bulunmaktadır.

\section{UYGULAMA ve ANALIZ}

Çalışmanın önceki bölümlerinde konuya giriş yapılarak önceki çalışmaların incelenmesi ve buradaki bilgilerle kavramsal çerçevenin oluşturulması sağlanmıştır. Ayrıca geliştirilen hipotezlerle işletmelerin teknolojik yetenekler, stratejik esneklik ve ürün inovasyonu arasındaki ilişkilerin teorik altyapısı sunulmuştur. Bu bölümde TR 63 Bölgesinde faaliyet gösteren mobilya imalatçısı işletmelerden elde edilen veriler ışı ğında hipotezlerin bu bağlamda test edilmesi sağlanacaktır.

Araştırma deseninin oluşturulmasında Zhou ve Wu (2010: 547) tarafından gerçekleştirilen çalışmada kullanılan ölçek Türkçe 'ye tercüme edilerek uygulanması 
sağlanmıştır. Uygulama öncesinde tercüme ile ilgili bir kısıtın oluşmaması için farklı uzmanlardan görüşler istenerek onların belirttiği noktalar gözden geçirilerek uygulama 176 kişi ile gerçekleştirilmiştir.

Bununla birlikte araştırmaya yönelik anket formları ve içerikler Kahramanmaraş Sütçü İmam Üniversitesi Rektörlüğü Sosyal ve Beşerî Bilimler Etik Kurulunun 28/08/2020 tarihli toplantısında görüşülmüş ve etik kurul onayı E.32294 (72321963-604.02.01) sayılı evrak ile tarafımıza iletilmiştir.

Anketin tasarımında demografik olarak katılımcıların yaşları, kıdemler, aylık gelirleri, cinsiyetleri, hangi ilde faaliyet gösterdikleri ve eğitim durumları incelenmiştir. Bu kapsamda elde edilen bulgular aşağıdaki tabloda sunulmaktadır.

Tablo 1. Katılımcıların Demografik Özellikleri

\begin{tabular}{|c|c|c|c|c|c|c|c|}
\hline & & $f$ & $\%$ & & 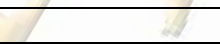 & $f$ & $\%$ \\
\hline \multirow{4}{*}{ Yaş } & 18 ila 25 yaş & 44 & 25,0 & \multirow{4}{*}{ Gelir } & 2000 ila $2350 \mathrm{TL}$ & 44 & 25,0 \\
\hline & 26 ila 32 yaş & 44 & 25,0 & & 2351 ila $2950 \mathrm{TL}$ & 49 & 27,8 \\
\hline & 33 ila 38 yaş & 45 & 25,6 & & 2951 ila 3450 TL & 38 & 21,6 \\
\hline & 39 ve üzeri & 43 & 24,4 & & 3451 ve üzeri & 45 & 25,6 \\
\hline \multirow{2}{*}{ Kidem } & 1 ila 5 yil & 87 & 49,4 & \multirow{2}{*}{ Cinsiyet } & Kadın & 60 & 34,1 \\
\hline & 6 ve üzeri & 89 & 50,6 & & Erkek & 116 & 65,9 \\
\hline \multirow{5}{*}{ Eğitim } & İlköğretim & 40 & 22,7 & \multirow{5}{*}{ II } & \multirow{2}{*}{ Kahramanmaraş } & \multirow{2}{*}{49} & \multirow{2}{*}{27,8} \\
\hline & Ortaöğretim & 54 & 30,7 & & & & \\
\hline & Önlisans/Lisans & 74 & 42,0 & & Hatay & 110 & 62,5 \\
\hline & Lisansüstü & 8 & 4,5 & & Osmaniye & 17 & 9,7 \\
\hline & Toplam & 176 & 100,0 & & Toplam & 176 & 100,0 \\
\hline
\end{tabular}

Örneklemin yaşları 18 ila 54 arasında değişmektedir. Kıdemleri ise 1 ila 33 yıl arasındadır. Aylık gelirleri ise 2000 TL ile 15000 TL arasında değişiklik göstermektedir. Verinin kolay yönetilebilmesi için eşite yakın varyanslarla bölünmesi sağlanmıştır. Katılımcıların erkek yoğun olduğu gözlenmektedir. Eğitim durumları incelendiğinde en çok lisans ve ön lisans mezunu olduğu görülmektedir. İllere göre katılım tabakalı örnekleme yöntemi kullanılarak gerçekleştirildiği için farklılık arz etmekle birlikte en yüksek katılım Hatay ilinden gerçekleşmiştir. Temsil açısından bir kısıtın olmadığı gözlendiği için verilerin analizine geçilmiştir. 
Tablo 2. Verilerin Güvenirliği ve Tanımsal İstatistikler

\begin{tabular}{|c|c|c|c|c|}
\hline & Aritmetik ortalama & $\begin{array}{c}\text { Standart } \\
\text { Sapma }\end{array}$ & $\begin{array}{c}\text { Önerme } \\
\text { Sayıs }\end{array}$ & $\begin{array}{c}\text { Cronbach } \\
\text { Alfa Skoru }\end{array}$ \\
\hline Teknolojik Yetenek & 3.92 & 1.06226 & 5 & .960 \\
\hline & $\begin{array}{c}\text { Aritmetik } \\
\text { Ortalama }\end{array}$ & $\begin{array}{c}\text { Standart } \\
\text { Sapma }\end{array}$ & $\begin{array}{c}\text { Önerme } \\
\text { Sayısı }\end{array}$ & $\begin{array}{c}\text { Cronbach } \\
\text { Alfa Skoru }\end{array}$ \\
\hline Stratejik Esneklik & 3.91 & .98383 & 6 & .917 \\
\hline \multicolumn{4}{|r|}{$\begin{array}{c}\text { Cronbach } \\
\text { Alfa Skoru }\end{array}$} \\
\hline Uriün İnovasyonu & $\begin{array}{c}\text { Aritmetik } \\
\text { Ortalama }\end{array}$ & $\begin{array}{c}\text { Standart } \\
\text { Sapma }\end{array}$ & $\begin{array}{c}\text { Önerme } \\
\text { Sayısı }\end{array}$ & .930 \\
\hline Faydada Değişim & 3.14 & 1.26543 & 5 & .910 \\
\hline Keşifte Değişim & 3.63 & 1.13388 & 5 & .817 \\
\hline Teknolojik Türbülans & 4.36 & .79324 & 4 & .698 \\
\hline Pazar Büyüklüğü & 3.94 & 1.02381 & 3 & \\
\hline
\end{tabular}

Verilerin analizinde ilk olarak ölçekteki boyutlara göre önermelerin güvenirlikleri incelenmiştir. Bu kapsamda bütün boyutlarla ilgili güvenilir sonuçların elde edildiği gözlenmektedir (Beraha ve diğerleri, 2018: 129). Ayrıca ölçek Likert tipi ve "Kesinlikle katılmıyorum" seçeneği ile başlayıp "Kesinlikle katılıyorum" seçeneği ile devam etmektedir. Buna göre elde edilen aritmetik ortalamalarda en yüksek değerin teknolojik türbülans boyutunda olduğu, en düşük değerin de faydada değişim boyutunda olduğu gözlenmektedir. Bütün boyutlar için üçten yüksek değerler elde edilmiş olduğundan kararsızım ile katılıyorum arasında değerlerin elde edildiği, ancak teknolojik türbülansta katılıyorum ile kesinlikle katılıyorum arasında bir değerin elde edilmiş olduğu gözlenmektedir. Standart sapmalar incelendiğinde örneklemin homojen bir dağılım sergilemiş olduğu anlaşılmaktadır.

Örneklemin evreni temsil kabiliyetinin olduğu ve elde edilen verilerin güvenirliği kanıtlandıktan sonra ankette sorulan demografik özelliklere göre istatistiki olarak anlamlı farkların olup olmadığının incelenmesi için varyans testleri gerçekleştirilmiştir. Bu kapsamda iki değişkeni olan boyutlar için T-testi, ikiden fazla hal alabilen boyutlar için de ANOVA testi yapılmıştır. 
Tablo 3. ANOVA Testi Sonuçları

\begin{tabular}{|c|c|c|c|c|c|c|c|}
\hline \multicolumn{8}{|c|}{ Yaş Gruplarına Göre ANOVA Sonuçları } \\
\hline & & $\begin{array}{l}\text { Sum of } \\
\text { Squares }\end{array}$ & $\mathrm{df}$ & $\begin{array}{c}\text { Mean } \\
\text { Square }\end{array}$ & $\mathrm{F}$ & Sig. & $\begin{array}{c}\text { Fark Olan } \\
\text { Gruplar }\end{array}$ \\
\hline \multirow{3}{*}{$\begin{array}{l}\text { Teknolojik } \\
\text { Yetenekler }\end{array}$} & Gruplar Arası & 4,430 & 3 & 1,477 & 1,316 & ,271 & \multirow{3}{*}{$\begin{array}{l}\text { Anlamlı } \\
\text { Fark yok }\end{array}$} \\
\hline & Grup İçi & 193,039 & 172 & 1,122 & & & \\
\hline & Toplam & 197,469 & 175 & & & & \\
\hline \multirow[t]{3}{*}{ Stratejik Esneklik } & Gruplar Arası & 15,585 & 3 & 5,195 & 5,810 & ,001 & \multirow{3}{*}{$\begin{array}{c}18 \text { ila } 25 \text { yaş> } \\
\text { Diğer tüm gruplar }\end{array}$} \\
\hline & Grup İçi & 153,800 & 172 & 894 & & & \\
\hline & Toplam & 169,385 & 175 & & & & \\
\hline \multirow[t]{3}{*}{ Fayda } & Gruplar Arası & 5,742 & 3 & 1,914 & 1,199 & ,312 & \multirow{3}{*}{$\begin{array}{c}\text { Anlamlı } \\
\text { Fark yok }\end{array}$} \\
\hline & Grup İçi & 274,490 & 172 & 1,596 & & & \\
\hline & Toplam & 280,232 & 175 & $3 \quad 2$ & & & \\
\hline \multirow[t]{3}{*}{ Keşif } & Gruplar Arası & 5,386 & 3 & 1,795 & 1,406 & 243 & \multirow{3}{*}{$\begin{array}{l}\text { Anlamlı } \\
\text { Fark yok }\end{array}$} \\
\hline & Grup İçi & 219,608 & 172 & 1,277 & & & \\
\hline & Toplam & 224,994 & 175 & & & & \\
\hline \multirow{3}{*}{$\begin{array}{l}\text { Teknolojik } \\
\text { Türbülans }\end{array}$} & Gruplar Arası & 6,448 & 3 & 2,149 & 3,566 & ,015 & \multirow{3}{*}{$\begin{array}{c}18 \text { ila } 25 \text { yaş> } \\
26 \text { ila } 32 \text { yaş; } \\
18 \text { ila } 25 \text { yaş> } \\
39 \text { ve üzeri yaş }\end{array}$} \\
\hline & Grup İçi & 103,668 & 172 &, 603 & & & \\
\hline & Toplam & 110,116 & 175 & & & & \\
\hline \multirow[t]{3}{*}{ Pazar Adaptasyonu } & Gruplar Arası & 5,300 & 3 & 1,767 & 1,706 & 168 & \multirow{3}{*}{$\begin{array}{l}\text { Anlamlı } \\
\text { Fark yok }\end{array}$} \\
\hline & Grup İçi & 178,132 & 172 & 1,036 & & & \\
\hline & Toplam & 183,432 & 175 & & & & \\
\hline
\end{tabular}

Gerçekleştirilen ANOVA testine göre teknolojik yetenekler bağlamında örneklemin vermiş olduğu cevaplarda istatistiki olarak anlamlı bir farkın olmadığı tespit edilmiştir $(F=1,316 ; p=, 271 \mathrm{df}=172: 3)$. Stratejik esneklik bağlamında elde edilen cevaplarda yaş gruplarına göre anlamlı farkların olduğu belirlenmiştir $(F=5,810 ; p=$ ,001 df=172: 3). Buna göre en genç yaş grubu olan 18 ila 25 yaş grubunun diğerlerinden daha yüksek algıya sahip olduğu gözlenmektedir. Ürün inovasyonunun boyutları için farklar incelendiğinde faydada değişim $(F=1,199 ; \mathrm{p}=, 312 \mathrm{df}=172: 3)$ boyutunda istatistiki olarak anlamlı bir farkın bulunmadığı gözlenmektedir. Bununla birlikte keşifte değişim boyutunda da anlamlı bir fark belirlenememektedir $(F=1,406 ; p=$,243 $\mathrm{df}=172: 3$ ). Teknolojik türbülans boyutuna gelindiğinde örneklemin vermiş olduğu cevaplarda istatistiki olarak anlamlı farkların olduğu görülmektedir $(F=3,566 ; p=, 015$ $\mathrm{df}=172: 3$ ). Buna göre 18 ila 25 yaş grubunun 26 ila 32 yaş ve 39 ve üzeri yaş gruplarına göre anlamlı şekilde yüksek algısının olduğu tespit edilmiştir. Pazara adaptasyon boyutunda ise istatistiki olarak anlamlı bir farkın olmadığ belirlenmiştir $(F=1,706 ; p=$ $, 168 \mathrm{df}=172: 3)$.

Cinsiyet değişkenine göre gerçekleştirilen testlerde örneklemin vermiş olduğu cevaplarda istatistiki olarak anlamlı bir farkın olmadığı tespit edilmiştir (Teknolojik Yetenek $(t=1,436 ; d f=174 ; p=, 153)$; Stratejik Esneklik $(t=1,342 ; d f=174 ; p=, 181)$; 
Faydada Değişim $(t=1,209 ; d f=174 ; p=$,228); Keşifte Değişim $(t=1,032 ; d f=174 ; p=$ ,303); Teknolojik Türbülans ( $t=1,392 ; d f=174 ; p=, 166)$; Pazara Adaptasyon $(t=1,414$; $\mathrm{df}=174 ; \mathrm{p}=, 159)$.

Tablo 4. ANOVA Testi Sonuçları

\begin{tabular}{|c|c|c|c|c|c|c|c|}
\hline \multicolumn{8}{|c|}{ Gelir Gruplarına Göre ANOVA Sonuçları } \\
\hline & & $\begin{array}{c}\text { Kareler } \\
\text { Toplamı }\end{array}$ & $\mathrm{df}$ & Ort. Kare & F & Anl. & $\begin{array}{l}\text { Fark olan } \\
\text { Gruplar }\end{array}$ \\
\hline \multirow{3}{*}{$\begin{array}{l}\text { Teknolojik } \\
\text { Yetenekler }\end{array}$} & Gruplar Aras1 & 12,853 & 3 & 4,284 & 3,991 & ,009 & \multirow{3}{*}{$\begin{array}{c}3451 \text { ve üzeri> } \\
2000 \text { ila } 2350 ; \\
3451 \text { ve üzeri> } \\
2351 \text { ila } 2950\end{array}$} \\
\hline & Grup İçi & 184,616 & 172 & 1,073 & & & \\
\hline & Toplam & 197,469 & 175 & & & & \\
\hline \multirow{3}{*}{$\begin{array}{l}\text { Stratejik } \\
\text { Esneklik }\end{array}$} & Gruplar Arası & 7,899 & 3 & 2,633 & 2,805 & 041 & \multirow{3}{*}{$\begin{array}{c}2000 \text { ila } 2350> \\
2351 \text { ila } 2950\end{array}$} \\
\hline & Grup İçi & 161,486 & 172 &, 939 & +2 & & \\
\hline & Toplam & 169,385 & 175 & & & & \\
\hline \multirow[t]{3}{*}{ Fayda } & Gruplar Aras1 & 11,935 & 3 & 3,978 & 2,550 & ,057 & \multirow{3}{*}{$\begin{array}{l}\text { Anlaml1 } \\
\text { Fark yok }\end{array}$} \\
\hline & Grup İçi & 268,297 & 172 & 1,560 & $\sqrt{2}$ & 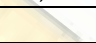 & \\
\hline & Toplam & 280,232 & 175 & & & & \\
\hline \multirow[t]{3}{*}{ Keşif } & Gruplar Arasi & 8,705 & 3 & 2,902 & 2,307 & ,078 & \multirow{3}{*}{$\begin{array}{l}\text { Anlamlı } \\
\text { Fark yok }\end{array}$} \\
\hline & Grup İçi & 216,289 & 172 & 1,257 & & (n) & \\
\hline & Toplam & 224,994 & 175 & & 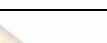 & ( & \\
\hline \multirow{3}{*}{$\begin{array}{l}\text { Teknolojik } \\
\text { Türbülans }\end{array}$} & Gruplar Arası & 2,703 & 3 & ,901 & 1,443 & ,232 & \multirow{3}{*}{$\begin{array}{l}\text { Anlamlı } \\
\text { Fark yok }\end{array}$} \\
\hline & Grup İçi & 107,414 & 172 & 624 & $x=$ & & \\
\hline & Toplam & 110,116 & 175 & & $x_{1}$ & & \\
\hline \multirow{3}{*}{$\begin{array}{c}\text { Pazar } \\
\text { Adaptasyonu }\end{array}$} & Gruplar Arası & 2,345 & 3 & ,782 &, 742 & ,528 & \multirow{3}{*}{$\begin{array}{l}\text { Anlamlı } \\
\text { Fark yok }\end{array}$} \\
\hline & Grup İçi & 181,087 & 172 & 1,053 & 8 & & \\
\hline & Toplam & 183,432 & 175 & $x$ & & & \\
\hline
\end{tabular}

Gelir gruplarına göre ANOVA testi sonuçları incelendiğinde teknolojik yetenek $(F=3,991 ; p=, 009 d f=172: 3)$ ve stratejik esneklik $(F=2,805 ; p=, 041 d f=172: 3)$ boyutlarında anlamlı farkların olduğu gözlenmektedir. Buna göre teknolojik yeteneklerde 3451 ve üzeri geliri olanlar 2000 ila 2350 TL ve 2351 ila 2950 TL geliri olanlardan daha yüksek algilara sahiptir. Stratejik esneklikle ilgili olarak da geliri 2000 ila 2350 TL olanların 2351 ila 2950 TL olanlardan daha yüksek bir algıya sahip olduğu tespit edilmiştir. Geriye kalan boyutlarla ilgili istatistiki olarak anlamlı farkların olmadığ1 belirlenmiştir (Faydada Değişim $(F=2,550 ; p=$,057 df= 172: 3); Keşifte Değişim (F= 2,307; $p=$,078 df= 172: 3); Teknolojik Türbülans $(F=1,443 ; p=$,232 df= 172: 3); Pazara Adaptasyon $(\mathrm{F}=, 742 ; \mathrm{p}=, 528 \mathrm{df}=172: 3)$. 
Tablo 5. T-Testi Sonuçları

\begin{tabular}{|c|c|c|c|c|c|c|}
\hline \multicolumn{7}{|c|}{ Kıdeme Göre T-testi sonuçları } \\
\hline & Kidem & $\mathrm{N}$ & $\bar{x}$ & Std. Sapma & Std. Hata & T-Testi Sonuçları \\
\hline \multirow{2}{*}{$\begin{array}{l}\text { Teknolojik } \\
\text { Yetenekler }\end{array}$} & 1 ila 5 yil & 87 & 3,8851 & ,95850 & ,10276 & \multirow[t]{2}{*}{$(\mathrm{t}=-, 520 ; \mathrm{df}=174 ; \mathrm{p}=, 604)$} \\
\hline & 6 ve üzeri & 89 & 3,9685 & 1,15872 & 12282 & \\
\hline \multirow{2}{*}{$\begin{array}{l}\text { Stratejik } \\
\text { Esneklik }\end{array}$} & 1 ila 5 yil & 87 & 4,2395 & ,83050 & 08904 & \multirow[t]{2}{*}{$(\mathrm{t}=4,613 ; \mathrm{df}=174 ; \mathrm{p}=, 000)$} \\
\hline & 6 ve üzeri & 89 & 3,5918 & 1,02031 & 10815 & \\
\hline \multirow[t]{2}{*}{ Fayda } & 1 ila 5 yil & 87 & 3,1678 & 1,26890 & 13604 & \multirow[t]{2}{*}{$(\mathrm{t}=, 255 ; \mathrm{df}=174 ; \mathrm{p}=, 799)$} \\
\hline & 6 ve üzeri & 89 & 3,1191 & 1,26876 & 13449 & \\
\hline \multirow[t]{2}{*}{ Keşif } & 1 ila 5 yil & 87 & 3,9218 & 1,04830 & 11239 & \multirow[t]{2}{*}{$(\mathrm{t}=3,473 ; \mathrm{df}=174 ; \mathrm{p}=, 001)$} \\
\hline & 6 ve üzeri & 89 & 3,3461 & 1,14763 & 12165 & \\
\hline \multirow{2}{*}{$\begin{array}{l}\text { Teknolojik } \\
\text { Türbülans }\end{array}$} & 1 ila 5 yil & 87 & 4,5402 & ,75663 & 08112 & \multirow[t]{2}{*}{$(\mathrm{t}=2,910 ; \mathrm{df}=174 ; \mathrm{p}=, 004)$} \\
\hline & 6 ve üzeri & 89 & 4,1994 & ,79610 & 08439 & \\
\hline \multirow{2}{*}{$\begin{array}{c}\text { Pazar } \\
\text { Adaptasyonu }\end{array}$} & 1 ila 5 yil & 87 & 3,9808 & 1,01965 & 10932 & \multirow[t]{2}{*}{$(\mathrm{t}=, 481 ; \mathrm{df}=174 ; \mathrm{p}=, 631)$} \\
\hline & 6 ve üzeri & 89 & 3,9064 & 1,03229 & 10942 & \\
\hline
\end{tabular}

Örneklemin kıdemine göre vermiş oldukları cevaplar incelendiğinde teknolojik yetenek $(\mathrm{t}=-, 520 ; \mathrm{df}=174 ; \mathrm{p}=, 604)$ boyutunda anlamlı bir farkın olmadı $\breve{g}_{1}$ gözlenmektedir. Ancak stratejik esneklik $(\mathrm{t}=4,613 ; \mathrm{df}=174 ; \mathrm{p}=, 000)$ boyutunda k1demi daha düşük olan grubun daha yüksek algıya sahip olduğu belirlenmiştir. Bunun yanında ürün inovasyonunun alt boyutlarından faydada değişim $(\mathrm{t}=, 255 ; \mathrm{df}=174 ; \mathrm{p}=$ ,799) boyutunda anlamlı bir fark tespit edilemezken keşifte değişim ( $\mathrm{t}=3,473 ; \mathrm{df}=174$ ; $=$,001) boyutunda kıdemi düşük olanların daha yüksek algısı olduğu belirlenmiştir. Benzer şekilde teknolojik türbülans $(\mathrm{t}=2,910 ; \mathrm{df}=174 ; \mathrm{p}=, 004)$ boyutunda da kıdemi 1 ila 5 yıl arasında olanların daha yüksek algısı olduğu ortaya konulmuştur. Son olarak pazara adaptasyon $(\mathrm{t}=, 481 ; \mathrm{df}=174 ; \mathrm{p}=, 631)$ boyutunda anlamlı bir farkın olmadı $\breve{\mathrm{g}}$ görülmektedir. 
Tablo 6. ANOVA Testi Sonuçları

\begin{tabular}{|c|c|c|c|c|c|c|c|}
\hline \multicolumn{8}{|c|}{ Ĕ̆itim Düzeyi ANOVA Sonuçları } \\
\hline & & $\begin{array}{c}\text { Kareler } \\
\text { Toplama }\end{array}$ & $\begin{array}{c}\text { Serbestlik } \\
\text { Derecesi }\end{array}$ & $\begin{array}{c}\text { Ortalama } \\
\text { Kare }\end{array}$ & F & Anlamlilık & $\begin{array}{c}\text { Fark } \\
\text { Olan gruplar }\end{array}$ \\
\hline \multirow{3}{*}{$\begin{array}{c}\text { Teknolojik } \\
\text { Yetenek }\end{array}$} & Gruplar Arası & 16,174 & 3 & 5,391 & 5,115 & ,002 & \multirow{3}{*}{$\begin{array}{l}\text { Lisansüstü> } \\
\text { İlköğretim; } \\
\text { Lisansüstü> } \\
\text { Ortaöğretim }\end{array}$} \\
\hline & Grup İçi & 181,295 & 172 & 1,054 & & & \\
\hline & Toplam & 197,469 & 175 & & & & \\
\hline \multirow{3}{*}{$\begin{array}{l}\text { Stratejik } \\
\text { Esneklik }\end{array}$} & Gruplar Arası & 7,017 & 3 & 2,339 & 2,478 & 063 & \multirow{3}{*}{$\begin{array}{l}\text { Anlamlı } \\
\text { fark yok }\end{array}$} \\
\hline & Grup İçi & 162,368 & 172 & ,944 & & & \\
\hline & Toplam & 169,385 & 175 & & & & \\
\hline \multirow[t]{3}{*}{ Fayda } & Gruplar Arası & 6,378 & 3 & 2,126 & 1,335 & 265 & \multirow{3}{*}{$\begin{array}{l}\text { Anlamlı } \\
\text { fark yok }\end{array}$} \\
\hline & Grup İçi & 273,854 & 172 & 1,592 & & & \\
\hline & Toplam & 280,232 & 175 & 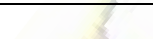 & & & \\
\hline \multirow[t]{3}{*}{ Keşif } & Gruplar Arası & 6,726 & 3 & 2,242 & 1,767 & 155 & \multirow{3}{*}{$\begin{array}{l}\text { Anlamlı } \\
\text { fark yok }\end{array}$} \\
\hline & Grup İçi & 218,268 & 172 & 1,269 & & & \\
\hline & Toplam & 224,994 & 175 & 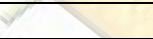 & 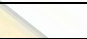 & & \\
\hline \multirow{3}{*}{$\begin{array}{l}\text { Teknolojik } \\
\text { Türbülans }\end{array}$} & Gruplar Arası & 1,539 & 3 &, 513 & 812 & 489 & \multirow{3}{*}{$\begin{array}{l}\text { Anlamlı } \\
\text { fark yok }\end{array}$} \\
\hline & Grup İçi & 108,577 & 172 & 631 & & & \\
\hline & Toplam & 110,116 & 175 & & & & \\
\hline \multirow{3}{*}{$\begin{array}{c}\text { Pazar } \\
\text { Adaptasyonu }\end{array}$} & Gruplar Arası & 4,247 & 3 & 1,416 & 1,359 & 257 & \multirow{3}{*}{$\begin{array}{l}\text { Anlamlı } \\
\text { fark yok }\end{array}$} \\
\hline & Grup İçi & 179,184 & 172 & 1,042 & & & \\
\hline & Toplam & 183,432 & 175 & & & 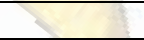 & \\
\hline
\end{tabular}

Eğitim düzeylerine göre gerçekleştirilen ANOVA testinde sadece teknolojik yetenek ( $F=5,115 ; \mathrm{p}=, 002 \mathrm{df}=172: 3)$ boyutunda anlamlı bir farkın olduğu tespit edilmiştir. Buna göre Lisansüstü eğitim düzeyinde olanların ilköğretim ve ortaöğretim düzeyinde eğitim düzeyine sahip olanlardan yüksek algıları olduğu belirlenmiştir. Geriye kalan boyutlarla ilgili istatistiki olarak anlamlı farklara rastlanmamıştır (stratejik esneklik ( $F=2,478 ; p=$,063 df= 172: 3); faydada değişim $(F=1,335 ; p=, 265 \mathrm{df}=$ 172 : 3); keşifte değişim ( $\mathrm{F}=1,767 ; \mathrm{p}=, 155 \mathrm{df}=172: 3)$; teknolojik türbülans $(\mathrm{F}=, 812$ $; \mathrm{p}=, 489 \mathrm{df}=172: 3)$; pazara adaptasyon $(\mathrm{F}=1,359 ; \mathrm{p}=, 257 \mathrm{df}=172: 3)$. 
Tablo 7. ANOVA Testi Sonuçları

\begin{tabular}{|c|c|c|c|c|c|c|c|}
\hline \multicolumn{8}{|c|}{ Illere göre ANOVA Sonuçları } \\
\hline & & $\begin{array}{c}\text { Kareler } \\
\text { Toplama }\end{array}$ & $\begin{array}{c}\text { Serbestlik } \\
\text { Derecesi } \\
\end{array}$ & $\begin{array}{c}\text { Ortalama } \\
\text { Kare }\end{array}$ & F & Anlamlilik & $\begin{array}{c}\text { Fark olan } \\
\text { Gruplar }\end{array}$ \\
\hline \multirow{3}{*}{$\begin{array}{l}\text { Teknolojik } \\
\text { Yetenek }\end{array}$} & Gruplar Arası & 138,970 & 2 & 69,485 & 205,489 & 000 & \multirow{3}{*}{$\begin{array}{c}\text { Kahramanmaraş } \\
\text { > Hatay; } \\
\text { Osmaniye }\end{array}$} \\
\hline & Grup İçi & 58,499 & 173 & ,338 & & & \\
\hline & Toplam & 197,469 & 175 & & & & \\
\hline \multirow{3}{*}{$\begin{array}{l}\text { Stratejik } \\
\text { Esneklik }\end{array}$} & Gruplar Arası & 33,907 & 2 & 16,954 & 21,649 & 000 & \multirow{3}{*}{$\begin{array}{c}\text { Kahramanmaraş> } \\
\text { Hatay; } \\
\text { Osmaniye }\end{array}$} \\
\hline & Grup İçi & 135,478 & 173 & ,783 & & & \\
\hline & Toplam & 169,385 & 175 & & & & \\
\hline \multirow[t]{3}{*}{ Fayda } & Gruplar Arası & 35,156 & 2 & 17,578 & 12,408 & 000 & \multirow{3}{*}{$\begin{array}{c}\text { Kahramanmaraş> } \\
\text { Osmaniye }\end{array}$} \\
\hline & Grup İçi & 245,076 & 173 & 1,417 & & & \\
\hline & Toplam & 280,232 & 175 & 3 & & & \\
\hline \multirow[t]{3}{*}{ Keşif } & Gruplar Arası & 27,254 & 2 & 13,627 & 11,922 & 000 & \multirow{3}{*}{$\begin{array}{c}\text { Kahramanmaraş> } \\
\text { Osmaniye }\end{array}$} \\
\hline & Grup İçi & 197,741 & 173 & 1,143 & & & \\
\hline & Toplam & 224,994 & 175 & & & & \\
\hline \multirow{3}{*}{$\begin{array}{l}\text { Teknolojik } \\
\text { Türbülans }\end{array}$} & Gruplar Arası & 18,241 & 2 & 9,120 & 17,174 & ,000 & \multirow{3}{*}{$\begin{array}{c}\text { Kahramanmaraş> } \\
\text { Osmaniye }\end{array}$} \\
\hline & Grup İçi & 91,875 & 173 &, 531 & & +3 & \\
\hline & Toplam & 110,116 & 175 & & & 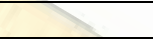 & \\
\hline \multirow{3}{*}{$\begin{array}{c}\text { Pazar } \\
\text { Adaptasyonu }\end{array}$} & Gruplar Arası & 12,451 & 2 & 6,226 & 6,299 &, 002 & \multirow{3}{*}{$\begin{array}{c}\text { Kahramanmaraş> } \\
\text { Osmaniye }\end{array}$} \\
\hline & Grup İçi & 170,980 & 173 & ,988 & & & \\
\hline & Toplam & 183,432 & 175 & & & & \\
\hline
\end{tabular}

İllere göre gerçekleştirilen ANOVA testinde bütün boyutlarda anlamlı farklar tespit edilmiştir (teknolojik yetenek $(\mathrm{F}=205,489 ; \mathrm{p}=, 000 \mathrm{df}=173: 2)$; stratejik esneklik $(\mathrm{F}=21,649 ; \mathrm{p}=, 000 \mathrm{df}=173: 2)$; faydada değişim $(\mathrm{F}=12,408 ; \mathrm{p}=, 000 \mathrm{df}=173: 2) ;$ keşifte değişim $(F=11,922 ; p=, 000 \mathrm{df}=173: 2)$; teknolojik türbülans $(F=17,174 ; p=, 000 \mathrm{df}=$ 173 : 2 ); pazara adaptasyon $(\mathrm{F}=6,299 ; \mathrm{p}=, 002 \mathrm{df}=173: 2)$. Buna göre teknolojik yeteneklerle stratejik esneklik boyutunda Kahramanmaraş'ın TR 63 Bölgesinin diğer illerinden yüksek algıya sahip olduğu gözlenmektedir. Geriye kalan boyutlarda ise Kahramanmaraş'tan katılanların Osmaniye ilinden katılanlara nazaran yüksek algısının olduğu belirlenmiştir.

Demografik özelliklerin ankete verilen cevaplarda ortaya çıkardığı farkların incelenmesinden sonra anketin boyutlarının birbiri ile nasıl etkileşim içinde olduğunun görülebilmesi için Pearson korelasyonu ile ilişkiler incelenmiştir.

Tablo 8. Boyutlar Arası Korelasyon Tablosu

\begin{tabular}{|c|c|c|c|c|c|}
\hline & $\begin{array}{l}\text { Teknolojik } \\
\text { Türbülans }\end{array}$ & $\begin{array}{l}\text { Stratejik } \\
\text { Esneklik }\end{array}$ & Faydada Değişim & Keşifte Değişim & $\begin{array}{l}\text { Teknolojik } \\
\text { Türbülans }\end{array}$ \\
\hline Stratejik Esneklik &, $521^{* *}$ & & & & \\
\hline Faydada Değişim & $426^{\text {** }}$ & , $464^{* *}$ & & & \\
\hline Keşifte Değişim & , $387^{* * *}$ &, $541^{* *}$ & $464^{* *}$ & & \\
\hline Teknolojik Türbülans & $334^{* *}$ &, $317^{* *}$ & $204^{* *}$ & $248^{* *}$ & \\
\hline Pazar Adaptasyonu & $353^{\text {*t }}$ & $458^{* *}$ & $234^{* *}$ & $336^{* *+}$ &, $398^{* *}$ \\
\hline
\end{tabular}

Gerçekleştirilen test sonucuna göre anketteki bütün boyutların birbiri ile pozitif yönde anlamlı biçimde ilişkili olduğu gözlenmektedir. En yüksek ilişki yükünün 
stratejik esneklikle keşifte değişim boyutları arasında olduğu belirlenmiştir. En düşük ilişki ise faydada değişim ile teknolojik türbülans arasında gerçekleşmektedir. Analizin buraya kadar olan kısmında verilerle ilgili bir problem olmadı̆̆ gözlenmektedir. Hipotezlerin test edilebilmesi için regresyon uygulanması planlanmıştır. Bunun gerçekleştirilmesi için ön şartların sağlanıp sağlanmadığının kontrolü için birtakım analizlere ihtiyaç olduğu görülmektedir. İlk olarak ölçekteki boyutların gerçekten de aynı faktör altında sıralanıp sıralanmadığının belirlenmesi için Keşif Amaçlı Faktör Analizi (KAFA) yapılmıştır.

Teknolojik yetenekler, stratejik esneklik ve ürün inovasyonu ile ilgili ayrı ayrı testler gerçekleştirilmiştir. Buna göre ilk olarak teknolojik yeteneklerin ele alınması sağlanmıştır. Beş önerme ile ölçülmeye çalışılan bu boyutla ilgili gerçekleştirilen test sonuçları bir faktörün olduğunu göstermektedir $(\mathrm{KMO}=0,894(\mathrm{p}<0.01)$; Açılanan Toplam Varyans $=\% 86,257)$.

Tablo 9. Teknolojik Yetenekler KFA

\begin{tabular}{|c|c|c|}
\hline Kodu & Önerme & Faktör yükü \\
\hline Teknolojik Yetenek 1 & Teknolojiye yönelik önemli bilgileri edinebilme & 0,904 \\
\hline Teknolojik Yetenek 2 & Yeni teknoloji fırsatlarının belirlenebilmesi & 0,889 \\
\hline Teknolojik Yetenek 3 & Teknolojik değişikliklere yanit verebilme & 0,891 \\
\hline Teknolojik Yetenek 4 & En son teknolojilere sahip olabilme/yönetebilme & 0,849 \\
\hline Teknolojik Yetenek 5 & Sürekli olarak bir dizi yenilik geliştirebilme & 0,779 \\
\hline
\end{tabular}

KFA kapsamında ikinci analiz ise stratejik esneklikle ilgili boyut üzerinden gerçekleştirilmiştir. Altı önerme ile ölçülmeye çalışılan bu boyutla ilgili gerçekleştirilen KFA tatminkâr sonuçlar ortaya çıkarmıştır $(\mathrm{KMO}=0,887(\mathrm{p}<0.01)$; Açıklanan Toplam Varyans $=\% 70,913)$.

Tablo 10. Stratejik Esneklik KFA

\begin{tabular}{|c|c|c|}
\hline Kodu & Önerme & Faktör yükü \\
\hline $\begin{array}{l}\text { Stratejik } \\
\text { Esneklik } 1\end{array}$ & $\begin{array}{c}\text { Pazarlama kaynaklarının (reklam, tanıtım ve dağıtım kaynakları dâhil) çok çeşitli ürünleri } \\
\text { pazarlamak için esnek bir şekilde tahsis edilmesi }\end{array}$ & 0,886 \\
\hline $\begin{array}{l}\text { Stratejik } \\
\text { Esneklik } 2\end{array}$ & Çok çeşitli ürün varyasyonları üretmek için üretim kaynaklarının esnek bir şekilde dağıtılması & 0,887 \\
\hline $\begin{array}{l}\text { Stratejik } \\
\text { Esneklik } 3\end{array}$ & $\begin{array}{c}\text { Çok çeşitli potansiyel ürün uygulamalarını desteklemek için ürün tasarımının (modüler ürün } \\
\text { tasarımı gibi) esnekliğinin sağlanması }\end{array}$ & 0,816 \\
\hline $\begin{array}{c}\text { Stratejik } \\
\text { Esneklik } 4\end{array}$ & $\begin{array}{c}\text { Ürün stratejilerini, firmanın hangi ürünleri sunmayı amaçladığı ve hangi pazar segmentini } \\
\text { hedefleyeceği açısından yeniden tanımlamak }\end{array}$ & 0,874 \\
\hline $\begin{array}{c}\text { Stratejik } \\
\text { Esneklik } 5\end{array}$ & $\begin{array}{c}\text { Firmanın amaçlanan ürünlerini hedeflenen pazarlara geliştirirken, üretirken ve teslim ederken } \\
\text { kullanabileceği kaynak zincirlerini yeniden yapilandırma }\end{array}$ & 0,836 \\
\hline $\begin{array}{l}\text { Stratejik } \\
\text { Esneklik } 6\end{array}$ & $\begin{array}{c}\begin{array}{c}\text { Firmanın amaçladığı ürün stratejilerini desteklemek için kuruluş kaynaklarını etkili bir şekilde } \\
\text { yeniden dağıtma }\end{array}\end{array}$ & 0,745 \\
\hline
\end{tabular}


KFA kapsamında gerçekleştirilen son analiz ise ürün inovasyonu ile ilgili boyutları içermektedir. Bu kapsamda dört boyutla ilgili analiz gerçekleştirilmiştir ve sonuçların tatminkâr olduğu gözlenmektedir $(\mathrm{KMO}=0,819(\mathrm{p}<0.01)$; Açılanan Toplam Varyans $=\% 73,729)$.

Tablo 11. Ürün İnovasyonu KFA

\begin{tabular}{|c|c|c|}
\hline Kodu & Önerme & $\begin{array}{c}\text { Faktör } \\
\text { yükü }\end{array}$ \\
\hline Fayda1 & Bilinen/benzer ürünler için mevcut bilgiler güncellendi/yükseltildi. &, 853 \\
\hline Fayda2 & Mevcut inovasyon operasyonlarının verimliliğini artıran olgun teknolojilerden yararlanmaya yatırım yapıldı. &, 877 \\
\hline Fayda3 & Mevcut çözümlere yakın müşteri sorunlarına çözüm aramada gelişmiş yetenekler &, 848 \\
\hline Fayda4 & Firmanın zaten zengin deneyime sahip olduğu ürün geliştirme süreçlerinde becerilerinin yükseltilmesi &, 835 \\
\hline Fayda5 & Mevcut yenilik faaliyetlerinin verimliliğini artırmak için bilgi ve becerilerin güçlendirilmesi &, 837 \\
\hline Keşif1 & Firma için tamamen yeni olan üretim teknolojileri ve becerileri edinildi. &, 816 \\
\hline Keşif2 & Sektöre tamamen yeni gelen ürün geliştirme becerileri ve süreçlerini öğrendi. &, 816 \\
\hline Keşif3 & İnovasyon için önemli olan tamamen yeni yönetim ve organizasyon becerileri edinildi &, 895 \\
\hline Keşif4 & Yeni teknolojinin finansmanı ve Ar-Ge personelinin eğitimi konusunda tamamen yeni beceriler öğrenildi. &, 855 \\
\hline Keşif5 & Önceden deneyimi olmayan alanlarda inovasyon becerilerinin güçlendirildi. &, 735 \\
\hline Tek.Tür1 & Bu sektördeki teknoloji hızla değişiyor &, 758 \\
\hline Tek.Tür2 & Teknolojik değişiklikler bu sektörde önemli firsatlar sunuyor &, 739 \\
\hline Tek.Tür3 & Bu sektördeki teknolojik atılımlar sayesinde çok sayıda yeni ürün fikri mümkün olmuştur. &, 869 \\
\hline Tek.Tür4 & Bu sektördeki teknolojinin önümüzdeki birkaç yıl içinde nerede olacağını tahmin etmek çok zor &, 790 \\
\hline Paz. Ad.1 & Son üç yllda bu sektörün büyüme oranı çok yüksektir. &, 733 \\
\hline Paz. Ad.2 & Bu sektörde pazar talebi hızla artıs göstermektedir. &, 845 \\
\hline Paz. Ad.3 & Bu sektörde kitlesel pazarlama firsatı săglamak için birçok potansiyel müşteri var. &, 691 \\
\hline
\end{tabular}

Analiz sonuçları incelendiğinde önermelerin faktör yükü olarak en yüksek belirttikleri faktörlerin boyutun diğer önermeleri ile aynı faktörde sıralandı ğ gözlenmektedir. Sadece stratejik esneklik boyutunda bir önerme 0,5'ten fazla faktör yükü göstermemiştir. Bu sonuç da $0,5^{\prime}$ e çok yakın olduğu için bir problem teşkil etmeyeceği düşünülmektedir. YEM gerçekleştirmek için ikinci aşama olan Doğrulayıcı Faktör Analizine (DFA) geçilebileceği görülmektedir. DFA için SPSS paket programının AMOS uzantısı kullanılmıştır.

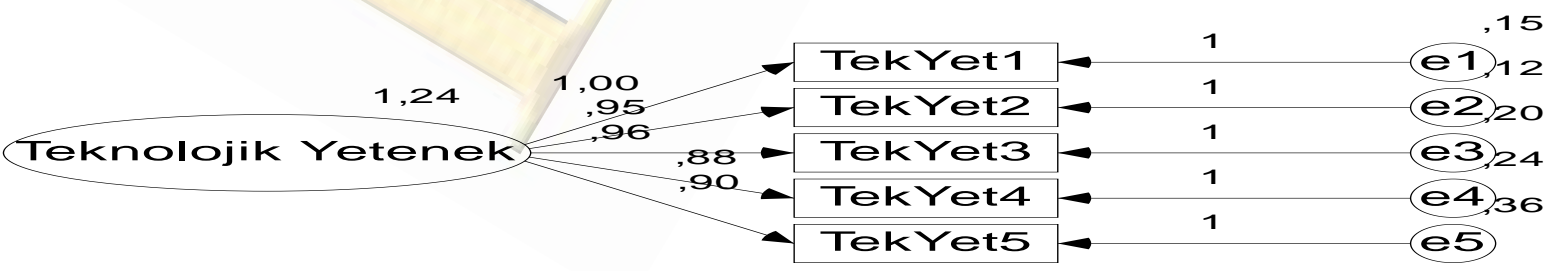

Şekil 1. Teknolojik Yetenekler ile İlgili DFA

Sınanan modelin veriye uyum sağladığı ve DFA için kabul edilebilir eşiğin üzerinde uyum indeksi sonuçları verdiği gözlenmiştir $(\mathrm{CMIN} / \mathrm{df}=1,930 ; \mathrm{GFI}=0,984$; AGFI=0,939; NFI=0,993; RFI=0,982; IFI=0,996; TLI=0,991; CFI=0,996; RMSEA=0,073). 


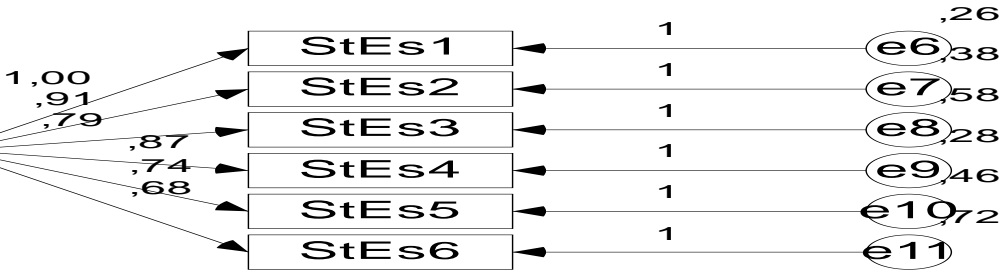

Şekil 2. Stratejik Esneklik ile İlgili DFA

Sınanan modelin veriye uyum sağladığı ve DFA için kabul edilebilir eşiğin üzerinde uyum indeksi sonuçları verdiği gözlenmiştir (CMIN/df= 1,685; GFI=0,976; AGFI=0,937; NFI=0,982; RFI=0,966; IFI=0,993; TLI=0,986; CFI=0,992; RMSEA=0,063).

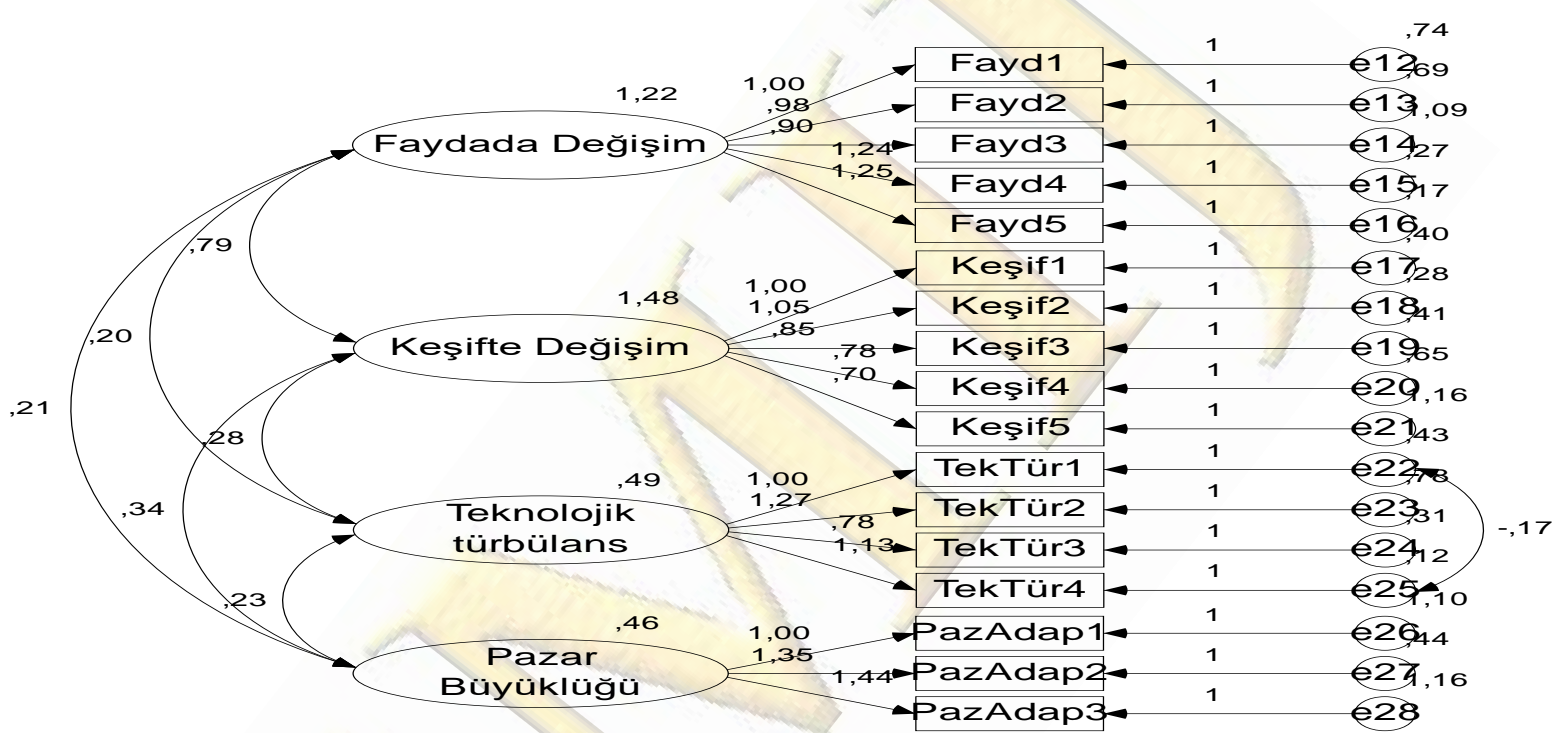

Şekil 3. Ürün İnovasyonu ile İlgili DFA

Sınanan modelin veriye uyum sağladığı ve DFA için kabul edilebilir eşiğin üzerinde uyum indeksi sonuçları verdiği gözlenmiştir (CMIN/df= 1,685; GFI=0,899; AGFI=0,854; NFI=0,918; RFI=0,895; IFI=0,965; TLI=0,954; CFI=0,964; RMSEA=0,063). 


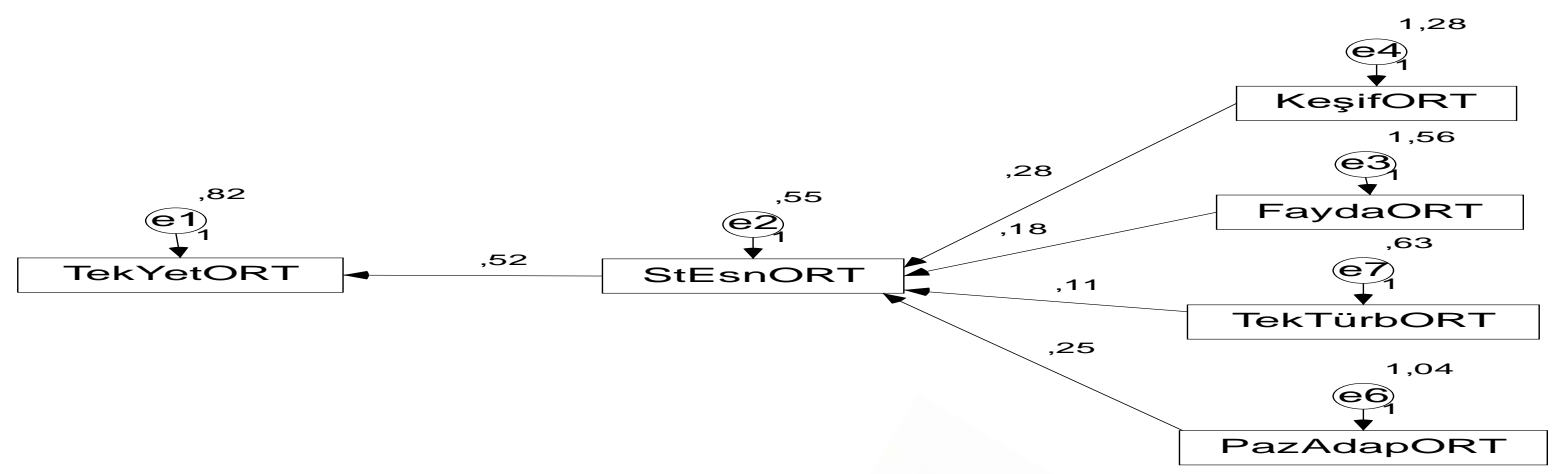

Şekil 4. Sınanan Yapısal Eşitlik Modeli

Modelin testiyle YEM için verilerin $(\mathrm{CMIN} / \mathrm{df}=8,802 ; \mathrm{GFI}=0,868$; $\mathrm{AGFI}=0,653$; $\mathrm{NFI}=0,742 ; \mathrm{RFI}=0,517 ; \mathrm{IFI}=0,765 ; \mathrm{TLI}=0,547 ; \mathrm{CFI}=0,758 ; \mathrm{RMSEA}=0,211)$ modele uymadığı gözlenmiştir. Dolayısıyla hipotezler hiyerarşik regresyon analizi ile test edilmiştir. Regresyon modeli ilk olarak teknolojik yeterliklerle stratejik esnekliği daha sonraki aşamasında da ürün inovasyonu ile ilgili boyutları içermektedir. $R$ kare değeri ilk model için 0,272 olarak belirlenmiş ve ürün inovasyonunun boyutları eklendiğinde bunun 0,350 düzeyine yükseldiği gözlenmiştir.

Tablo 12. Regresyon Analizi

\begin{tabular}{|c|c|c|c|c|c|c|}
\hline & \multirow[t]{2}{*}{ Model } & \multirow{2}{*}{$\begin{array}{c}\begin{array}{c}\text { Standardize } \\
\text { Olmayan } \\
\text { Katsayılar }\end{array} \\
\text { B } \\
\end{array}$} & \multicolumn{2}{|c|}{$\begin{array}{l}\text { Standardize } \\
\text { Katsayılar }\end{array}$} & \multirow[t]{2}{*}{$\mathrm{t}$} & \multirow[t]{2}{*}{ Anlamlilık } \\
\hline & & & Std. Hata & Beta & & \\
\hline \multirow[t]{2}{*}{1} & (Sabit) & 1,725 & ,282 & & 6,123 & 000 \\
\hline & Stratejik Esneklik & 563 & ,070 &, 521 & 8,062 & 000 \\
\hline \multirow[t]{6}{*}{2} & (Sabit) & 678 & 407 & & 1,667 & 097 \\
\hline & Stratejik Esneklik & ,333 & ,088 & ,309 & 3,768 & 000 \\
\hline & Fayda & ,172 & ,061 & 205 & 2,816 & ,005 \\
\hline & Keşif & ,056 & ,072 & ,060 & ,770 & 442 \\
\hline & Teknolojik Türbülans & ,195 & ,092 & 145 & 2,122 & 035 \\
\hline & Pazar Adaptasyonu & ,089 & 076 & 086 & 1,169 & 244 \\
\hline
\end{tabular}

Regresyon analizi sonuçlarına göre teknolojik yetenekler stratejik esneklikten Beta katsayısına bakıldığında 0,521 düzeyinde $(p<0.01)$ etkilenmektedir. Ayrıca stratejik esnekliğin ürün inovasyonu ile teknolojik yeteneklerin arasındaki aracı rolü $\operatorname{artan} R^{2}$ değeri ile ortaya çıkmaktadır. Bunlarla birlikte ürün inovasyonunun boyutları olan faydada değişim $(\beta=0,205 ; p<0.01)$, keşifte değişim $(\beta=0,060 ; p>0.05)$, teknolojik türbülans $(\beta=0,145 ; p<0.05)$ ve pazara adaptasyon $(\beta=0,086 ; p>0.05)$ olmak üzere teknolojik yeteneklerle ilişkileri rapor edilmiştir. Böylece faydada değişim ve teknolojik türbülans boyutlarında anlamlı ilişkilerin olduğu görülmektedir. 
Tablo 13. Hipotez Testi Sonuçları

\begin{tabular}{|c|c|}
\hline Hipotez & Test sonucu \\
\hline $\begin{array}{c}\text { H1- İ̧letmelerin teknolojik yeterlikleri stratejik esneklikleri ve ürün inovasyonu kabiliyetlerinden pozitif } \\
\text { etkilenmektedir. }\end{array}$ & Kabul edildi \\
\hline H2- Stratejik esneklik teknolojik yeteneklerle ürün inovasyonu ile olumlu biçimde ilişkilidir. & Kabul edildi \\
\hline $\begin{array}{c}\text { H3- Ürün inovasyonu pazara adaptasyonu kolaylaştırdığı gibi stratejik esneklik ve teknolojik yetenekler } \\
\text { üzerinde de olumlu etkiler yapmaktadır. }\end{array}$ & Kabul edildi \\
\hline
\end{tabular}

Buna göre ürün inovasyonunun boyutları stratejik esnekliği olumlu yönde etkilemektedir. Ayrıca stratejik esneklikte teknolojik yetenekleri önemli oranda etkilemektedir. Etki değerleri incelendiğinde pazar büyüklüğünün diğer ürün inovasyonu değişkenlerinde üçte bire yakın düzeylerde etkili olduğu gözlenmektedir. Ayrıca keşif ile faydada değişimle birlikte teknolojik türbülansın stratejik esnekliği onda bir ila üçte bire yakın oranlarda etkilediği ortaya konulmuştur. Bunlarla birlikte asıl önemli olan bulgulardan birisi de stratejik esnekliğin teknolojik yeteneklerin yarısına yakınını açıklayabildiğidir. Bu bulgular TR 63 bölgesinde mobilya imalatı yapanlarda Zhou ve Wu (2010: 547)'nun modelinin gerçekleştiğini göstermektedir. Elde edilen bulguların tartışılması ve araştırmacılarla uygulayıcılara tavsiyelerde bulunulması da çalışmanın bir sonraki bölümünde sunulmuştur.

\section{SONUÇ, KISIT ve ÖNERILER}

Çalışmanın bundan önceki bölümlerinde yazın taramasına bağlı olarak kavramsal çevçeve ile birlikte ampirik olarak gerçekleştirilen araştırmanın sonuçları paylaşılmıştır. Bu kısımda ise önceki çalışmaların bulguları ile birlikte mevcut çalışmanın sonuçları tartışılarak kullanıcı ve araştırmacıların uygulayabilecekleri birtakım öneriler sunulması planlanmaktadır.

İşletmeler artan rekabet ve sürekli değişen pazar koşulları ile birlikte dinamik biçimde uygulamalar geliştirmek durumunda kalmaktadır (Lei ve diğerleri, 1996: 501). Böylece stratejik esnekliğe ihtiyaç duydukları anlaşılmaktadır. Ancak stratejik esneklikten fayda sağlayabilmeleri için teknolojik olanaklardan da maksimum düzeyde yararlanmak zorundadır. Teknoloji ediniminin getireceği karmaşanın önlenmesi için de örgütsel yapının buna hazırlıklı hale getirilmesi önerilmektedir (Sanchez ve Mahoney, 1996: 63). Ayrica pazarla temas noktaları olan mal ve hizmetlerinde yapacakları değişikliklerle de uyum kabiliyeti kazanmaktadırlar. Bu bakış açısıyla başladığımız çalışmada TR 63 bölgesinde mobilya imalatı gerçekleştiren 
firmalarda Zhou ve $\mathrm{Wu}$ (2010: 547)'nun modelinin geçerli olup olmadığının incelenmesi ile yukarıdaki tartışmanın geçerliği olup olmadığının belirlenmesi amaçlanmıştır.

Araştırma kapsamında 176 kişiden elde edilen verilerin analizi ile modelin bu bağlamda da doğrulandığı gözlenmektedir. Bulgulardan yola çıkıldığında yazındaki pek çok çalışmanın sonuçlarının desteklendiği gözlenmektedir. Li ve diğerleri (2017: 471), Li ve diğerleri (2010: 300), Cabello-Medina ve diğerleri (2006: 80), Bock ve diğerleri (2010: 1) ile Beraha ve diğerleri (2018: 129) stratejik esneklik yükseldiğinde ürün inovasyonunun arttığını rapor etmektedir. Mevcut çalışmada da aynı sonuç elde edilmiştir. Buradan yola çıkarak kaynakların esnek biçimde dağıtımının önemli bir fayda sağlayacağı anlaşılmaktadır. Bierly ve diğerleri (1996: 368) ise stratejik esnekliğin nicel olarak ölçümü için kullanılabilecek ölçeklere ihtiyaç olduğunu belirtmektedir ve bizim çalışmamızda uyarladığımız ölçeğin güvenilir ve geçerli sonuçlar verdiği gözlenmektedir.

Diğer taraftan Branzei ve Vertinsky (2006: 75) işletmelerin teknoloji yönetim becerileri kapsamında teknolojik yeterliklerinin üst düzeylerde olması gerektiğini belirtmektedir. TR63 bölgesindeki mobilya imalatçıları da ölçek bakımından KOBİ niteliğinde olmalarına rağmen teknolojik yetenekler bakımından yüksek sayılabilecek bir alg1 belirtmektedir. Yalçınkaya ve diğerleri (2007: 63) ise teknoloji ediniminde keşifle birlikte uyum süreçlerinin yürütülmesi gerektiğini vurgulamaktadır. Mevcut çalışmada keşif ve pazarlara uyumla ilgili yüksek ortalamalar elde edilmiştir. Zhou ve Wu (2010: 547) da aynı duruma vurgu yaparak ürün inovasyonunda daha esnek yapıya sahip olunduğunda stratejik esneklik için de hareket alanı elde edilebileceğini göstermektedir.

Benzer biçimde Santos-Vijande ve diğerleri (2012: 1079) ve Chen ve diğerleri (2017: 10) işletmelerin stratejik esnekliği arttığında işletme performanslarının da yükseldiğini göstermektedir. Mevcut çalışmada elde edilen bulgular ters yorumlandığında pazara adaptasyon konusunda benzer bulguların elde edilebileceği görülmektedir. Fan ve diğerleri (2013: 187) ise teknolojik türbülansın arttı̆̆1 zamanlarda işletmelerin stratejik esnekliğinin artması gerektiğini göstermektedir. 
Ayrıca Lyytinen ve diğerleri (2016: 47) ve Lew ve Sinkovics (2013: 13) işletmenin işlevselliğinin ortaya çıkaracağ1 etkileşim ağ1 ile doğru orantılı olduğunu göstermektedir. Bizim çalışmamızda da hem stratejik esneklik hem de teknolojik yetenekler bakımından yüksek algıların olduğu gözlenmektedir. Bunun pazara adaptasyon konusunda da avantaj sağladığı anlaşılmaktadır. Bu bağlamda Kamasak ve diğerleri (2016: 126) de pazara uyumun işletmeler için faydalı sonuçlar ortaya çıkarabileceğini rapor etmektedir. Benzer sonuçlara Rajala ve diğerleri (2012: 1368) de değinmektedir. Bunlarla birlikte Worren ve diğerleri (2002: 1123) işletmelerin günümüz koşullarından çok kendilerini gelecekteki koşullara uydurması gerektiğine işaret etmektedir. Bunun yolunun da öğrenen örgütler şeklinde bir tasarımla hareket edilmesinden geçtiği düşünülmektedir.

Araştırmacılara yönelik olarak elde edilen sonuçlar incelendiğinde HervasOliver ve diğerleri (2014: 873) inovasyon, teknolojik yetenekler ve stratejik esneklik konusunda akademinin daha fazla yayın ortaya koyması gerektiğini göstermektedir. Mevcut çalışma bu konudaki eksiğin giderilmesine yardımcı olduğu gibi onların çağrısını da göstererek dinamik bir konu olduğunu yinelemektedir. Bununla birlikte Verdu-Jover ve diğerleri (2005: 131) araştırmalarının kapsamının birkaç sektör üzerinde yoğunlaşmış olduğu için dar olduğunu ve sonuçlarının genellenemeyeceğini belirtmektedir. Aynı şekilde mevcut çalışmada da sadece bir sektör ve üç ili kapsayan sonuçlar içerilmektedir. Dolayısıyla sonuçlarının genellenmesi için daha geniş kapsamlı çalışmalara ihtiyaç duyulmaktadır.

Bütün bu tartışmalar bir arada değerlendirildiğinde işletmelerin teknolojik yetenekler bakımından kendilerini en üst düzeye çıkaracak şekilde insan kaynakları politikaları uygulamaları ve nitelikli işgücünü oluşturma ve elinde tutmaya yönelik çaba sarf etmeleri gerektiği düşünülmektedir. Ayrıca mevcut süreçleri sürekli olarak gözden geçirip mükemmelleştirmeye yönelik gayret göstermelerinin de kendilerine fayda sağlayacağı umulmaktadır. Son söz olarak katma değeri yüksek ürünlerle ancak ülkelerin ekonomilerinin kalkınabileceğini, bunu gerçekleştirmek için de nitelikli işgücünü oluşturacak politikalara ihtiyaç olduğunu hatırlatarak yazına faydalı bir çalışmanın gerçekleştirilmiş olduğu ümit edilmektedir. 


\section{KAYNAKLAR}

Beraha, A., Bingol, D., Ozkan-Canbolat, E., \& Szczygiel, N. (2018). The effect of strategic flexibility configurations on product innovation. European Journal of Management and Business Economics. 27(2), 129140.

Bierly, P. E., \& Chakrabarti, A. K. (1996). Technological learning, strategic flexibility, and new product development in the pharmaceutical industry. IEEE Transactions on Engineering Management, 43(4), 368380.

Bock, A. J., Opsahl, T., George, G., \& Gann, D. M. (2012). The effects of culture and structure on strategic flexibility during business model innovation. Journal of Management studies, 49(2), 279-305.

Bock, A., Opsahl, T., \& George, G., (2010, February). Business model innovations and strategic flexibility: A study of the effects of informal and formal organization. In Proceedings of the Sumantra Ghoshal Conference for Managerially Relevant Research, London, UK (Vol. 18).

Branzei, O., \& Vertinsky, I. (2006). Strategic pathways to product innovation capabilities in SMEs. Journal of Business Venturing, 21(1), 75-105.

Cabello-Medina, C., Carmona-Lavado, A., \& Valle-Cabrera, R. (2006). Identifying the variables associated with types of innovation, radical or incremental: strategic flexibility, organisation and context. International Journal of Technology Management, 35(1-4), 80-106.

Chen, Y., Wang, Y., Nevo, S., Benitez, J., \& Kou, G. (2017). Improving strategic flexibility with information technologies: insights for firm performance in an emerging economy. Journal of Information Technology, 32(1), 10-25.

Fan, Z., Wu, D., \& Wu, X. (2013). Proactive and reactive strategic flexibility in coping with environmental change in innovation. Asian Journal of Technology Innovation, 21(2), 187-201.

Hervas-Oliver, J. L., Sempere-Ripoll, F., \& Boronat-Moll, C. (2014). Process innovation strategy in SMEs, organizational innovation and performance: a misleading debate?. Small business economics, 43(4), 873886.

Hitt, M. A., Keats, B. W., \& DeMarie, S. M. (1998). Navigating in the new competitive landscape: Building strategic flexibility and competitive advantage in the 21st century. Academy of Management Perspectives, 12(4), 22-42.

Jajja, M. S. S., Kannan, V. R., Brah, S. A., \& Hassan, S. Z. (2017). Linkages between firm innovation strategy, suppliers, product innovation, and business performance. International Journal of Operations $\mathcal{E}$ Production Management. 37(8), 1064-1075.

Kamasak, R., Yavuz, M., Karagulle, A. O., \& Agca, T. (2016). Importance of strategic flexibility on the knowledge and innovation relationship: an emerging market study. Procedia-Social and Behavioral Sciences, 229, 126-132.

Kortmann, S., Gelhard, C., Zimmermann, C., \& Piller, F. T. (2014). Linking strategic flexibility and operational efficiency: The mediating role of ambidextrous operational capabilities. Journal of Operations Management, 32(7-8), 475-490.

Lei, D., Hitt, M. A., \& Goldhar, J. D. (1996). Advanced manufacturing technology: organizational design and strategic flexibility. Organization Studies, 17(3), 501-523. 
Lew, Y. K., \& Sinkovics, R. R. (2013). Crossing borders and industry sectors: behavioral governance in strategic alliances and product innovation for competitive advantage. Long Range Planning, 46(1-2), 1338.

Li, Y., Li, P. P., Wang, H., \& Ma, Y. (2017). How do resource structuring and strategic flexibility interact to shape radical innovation?. Journal of Product Innovation Management, 34(4), 471-491.

Li, Y., Zhongfeng, S., \& Yi, L. (2010). Can strategic flexibility help firms profit from product innovation?. Technovation, 30(5-6), 300-309.

Lyytinen, K., Yoo, Y., \& Boland Jr, R. J. (2016). Digital product innovation within four classes of innovation networks. Information Systems Journal, 26(1), 47-75.

Rajala, R., Westerlund, M., \& Möller, K. (2012). Strategic flexibility in open innovation-designing business models for open source software. European Journal of Marketing. 46(10), 1368-1388.

Sanchez, R., \& Mahoney, J. T. (1996). Modularity, flexibility, and knowledge management in product and organization design. Strategic management journal, 17(S2), 63-76.

Santos-Vijande, M. L., López-Sánchez, J. Á., \& Trespalacios, J. A. (2012). How organizational learning affects a firm's flexibility, competitive strategy, and performance. Journal of business research, 65(8), 10791089.

Schneider, S., \& Spieth, P. (2014). Business model innovation and strategic flexibility: insights from an experimental research design. International Journal of Innovation Management, 18(06), 1440009.

Singh, D., Oberoi, J. S., \& Ahuja, I. S. (2013). An empirical investigation of dynamic capabilities in managing strategic flexibility in manufacturing organizations. Management Decision. 51(7), 1442-1461.

Tamayo-Torres, I., Ruiz-Moreno, A., \& Verdú, A. J. (2010). The moderating effect of innovative capacity on the relationship between real options and strategic flexibility. Industrial Marketing Management, 39(7), 1120-1127.

Tutar, H., Nart, S., \& Bingöl, D. (2015). The effects of strategic orientations on innovation capabilities and market performance: The case of ASEM. Procedia-Social and Behavioral Sciences, 207, 709-719.

Verdu-Jover, A. J., Llorens-Montes, J. F., \& Garcia-Morales, V. J. (2005). Flexibility, fit and innovative capacity: an empirical examination. International Journal of Technology Management, 30(1-2), 131-146.

Worren, N., Moore, K., \& Cardona, P. (2002). Modularity, strategic flexibility, and firm performance: a study of the home appliance industry. Strategic management journal, 23(12), 1123-1140.

Yalçınkaya, G., Calantone, R. J., \& Griffith, D. A. (2007). An examination of exploration and exploitation capabilities: Implications for product innovation and market performance. Journal of International Marketing, 15(4), 63-93.

Zhang, M. J. (2006). IS support for strategic flexibility, environmental dynamism, and firm performance. Journal of Managerial Issues, 18(1), 84-103.

Zhou, K. Z., \& Wu, F. (2010). Technological capability, strategic flexibility, and product innovation. Strategic Management Journal, 31(5), 547-561. 


\section{ETIKK KURUL İZINN BELGESI}

T.C.

KAHRAMANMARAS SÜTÇÜ IMMAM ÜNIVERSITTESİ REKTÖRLÜĞÜ Sosyal ve Beşeri Bilimler Etik Kurulu

Say1 : 72321963-604.02.01

Konu : Başvurular ve Proje Önerileri

\section{ULUSLARARASI TİCARET VE LOJISTİK BÖLÜM BAŞKANLIĞINA}

İlgi : 21/07/2020 tarihli ve 27691 sayılı yazı,

Kurulumuzdan istemiş olduğunuz etik kurul karanı ekte gönderilmiştir. Gereğini bilgilerinize arz/rica ederim.

e-imzalıdır

Prof. Dr. Nusret GÖKSU

Kurul Başkanı

Ek: Sosyal ve Beşeri Bilimler Etik Kurulu

28.08.2020 Tarih ve 2020-24 Sayll Karanı (3

sayfa)

Mevcut Elektronik İmzalar

NUSRET GÖKSU (Sosyal ve Beşeri Bilimler Etik Kurulu - Kurul Başkanı) 28/08/2020 16:10

\footnotetext{
Kahramanmaraş Sütçü İmam Üniversitesi Avşar Kampüsü, 46100 - $\quad$ Bilgi İçin: Mehmet TAKALAK Onikişubat/Kahramanmaras

Telefon No:03443002701 Faks No: 03443002702

Unvan: Sekreter

E-Posta: genelsekreterlik@1ksu edu. tr Internet Adresi: www. ksu. edu. tr
} 
T.C.

KAHRAMANMARAS SÜTÇÜ IMAM ÜNIVERSITESI SOSYAL VE BEȘERI BILIMLER ETIK KURUL KARARLARI

Toplantı Tarihi: 28.08 .2020

Toplantı Sayısı: 2020/24

Üniversitemiz Sosyal ve Beşeri Bilimleri Etik Kurulu, Kurul Başkanı Prof. Dr. Nusret GÖKSU'nun Başkanlığında toplanarak aşağıdaki kararları almıştır.

\section{KARAR 1 :}

Dr. Öğr. Üyesi Arif Selim EREN'in 21.07.2020 Tarihli dilekçesi ve ekleri Prof. Dr. Ahmet NALÇACI (raportör) 27.08.2020 tarih ve E. 32037 sayılı raporu görüşüldü.

Üniversitemiz Öğretim Üyelerinden Dr. Öğr. Üyesi Arif Selim EREN'in "Teknolojik Yetenekler, Stratejik esneklik ve Ürün İnovasyonu Arasındaki İlişkilerin Tespiti: TR63 Bölgesindeki Mobilya İmalatçıları Üzerine Bir Araştırma" başlıklı çalışmasında kullanmak için uygulanacak açık uçlu görüşme formu (ankette yer alan soru, önerme ve/veya ölçeklerin alıntılanmasına yönelik akademik alıntılanma kurallarına uyma zorunluluğu araştırmayı yapan akademisyen ve varsa danışmanlığını yaptığı ögrenciye ait olmak koşuluyla) uygulama talebinin uygun olduğuna oylama sonucunda oy birliği ile;

Karar verildi

\section{KARAR 2 :}

Dr. Öğr. Üyesi İsmail YELPAZE'nin 12.08.2020 Tarihli dilekçesi ve ekleri Prof. Dr. Ahmet NALÇACI (raportör) 27.08.2020 tarih ve E. 32043 sayılı raporu görüşüldü.

Üniversitemiz Öğretim Üyelerinden Dr. Öğr. Üyesi İsmail YELPAZE'nin " Psikodrama grup terapisinin, sığınmacıların travmatik yaşantılarının tedavisindeki etkisinin incelenmesi" başlıklı çalışmasında kullanmak için uygulanacak açık uçlu görüsme formu (ankette yer alan soru, önerme ve/veya ölçeklerin alıntılanmasına yönelik akademik alıntılanma kurallarına uyma zorunluluğu araştırmayı yapan akademisyen ve varsa danışmanlığını yaptığı öğrenciye ait olmak koşuluyla) Kahramanmaraş Sütçü İmam Üniversitesi'nde eğitim gören sığınmacı olarak Türkiye'de bulunan öğrencilere uygulanacaktır. uygulama talebinin uygun olduğuna oylama sonucunda oy birliği ile;

Karar verildi

\section{KARAR 3}

Doç. Dr. Erkan Hasan ATALMIȘ’ın 13.08.2020 Tarihli dilekçesi ve ekleri Prof. Dr. Ahmet NALÇACI (raportör) 27.08.2020 tarih ve E. 32034 sayılı raporu görüşüldü.

Üniversitemizin Eğitim Fakültesi - Eğitim Bilimleri Bölümü Yüksek lisans öğrencisi İbrahim TAȘDEMIR'ın "Okul Müdürlerinin; Paternalist (Babacan) Liderlik Davranışlarıyla Yaratıcı Liderlik Özellikleri Arasındaki İlişki: Kahramanmaraş İli Örneği" konulu tezde kullanmak için uygulanacak açık uçlu görüșme formu (ankette yer alan soru, önerme ve/veya ölçeklerin alıntılanmasına yönelik akademik alıntılanma kurallarına uyma zorunluluğu araștırmayı yapan akademisyen ve varsa danışmanlığını yaptığı ögrenciye ait olmak koşuluyla) Kahramanmaraş ilinde bulunan Milli Eğitim Bakanlığına bağlı okullarda görev yapan ögretmenlere uygulama talebinin uygun olduğuna oylama sonucunda oy birliği ile;

Karar verildi. 


\section{KARAR 4 :}

Dr. Öğr. Üyesi Yusuf ERGEN'in 21.05.2020 Tarihli dilekçesi ve ekleri Prof. Dr. Ahmet NALÇACI (raportör) 27.08.2020 tarih ve E. 32028 sayılı raporu görüşüldü.

Üniversitemiz Öğretim Üyelerinden Dr. Öğr. Üyesi Yusuf ERGEN'in "Sınıf Öğretmeni Adaylarının STEM Eğitim Yaklaşımı Farkındalıkları ve İlkokulda Uygulanabilirliğine İlişkin Görüşleri" başlıklı çalışmasında kullanmak için uygulanacak açık uçlu görüșme formu (ankette yer alan soru, önerme ve/veya ölçeklerin alıntılanmasına yönelik akademik alıntılanma kurallarına uyma zorunluluğu araștırmayı yapan akademisyen ve varsa danıșmanlığını yaptı̆̆ı öğrenciye ait olmak koşuluyla) Ondokuz Mayıs Üniversitesi, Kahramanmaraş Sütçü İmam Üniversitesi ve Bayburt Üniversitesi Eğitim Fakültelerinin Temel Eğitim Bölümü Sınıf Öğretmenliği Programı'nda öğrenim gören 3. ve 4. sınıf ögrencilerine uygulama talebinin uygun olduğuna oylama sonucunda oy birliği ile;

Karar verildi

\section{KARAR 5 :}

Dr. Öğr. Üyesi Züleyha YILDIRIM YAKAR'ın 10.07.2020 Tarihli dilekçesi ve ekleri Prof. Dr. Ahmet NALÇACI (raportör) 26.08.2020 tarih ve E. 31920 sayılı raporu görüşüldü.

Üniversitemiz Öğretim Üyelerinden Dr. Öğr. Üyesi Züleyha YILDIRIM YAKAR'ın "Ortaokul Matematik Dersinde Yapılandırmacılığa Dayalı Öğretim İlkelerinin Uygulanma Düzeyine İlișkin Öğrenci Görüşleri" başlıklı çalışmasında kullanmak için uygulanacak açık uçlu görüşme formu (ankette yer alan soru, önerme ve/veya ölçeklerin alıntılanmasına yönelik akademik alıntılanma kurallarına uyma zorunluluğu araștırmayı yapan akademisyen ve varsa danışmanlığını yaptığı öğrenciye ait olmak koşuluyla) uygulama talebinin uygun olduğuna oylama sonucunda oy birliği ile;

Karar verildi

\section{KARAR 6 :}

Dr. Öğrt. Üyesi Soner OKAN’nın 10.06.2020 Tarihli dilekçesi ve ekleri Prof. Dr. Mehmet TIRAȘ (raportör) 26.08.2020 tarih ve E. 31916 sayılı raporu görüșüldü.

Üniversitemiz Öğretim Üyelerinden Dr. Öğrt. Üyesi Soner OKAN'nın " Grascha- Reichmann Biliş Ötesi Farkındalık Envanteri ve Öğrenme Stilleri Ölçeği" başlıklı çalışmasında kullanmak için uygulanacak açık uçlu görüşme formu (ankette yer alan soru, önerme ve/veya ölçeklerin alıntılanmasına yönelik akademik alıntılanma kurallarına uyma zorunluluğu araștırmayı yapan akademisyen ve varsa danıșmanlığını yaptığı ögrenciye ait olmak koşuluyla) KSÜ Güzel Sanatlar Fakültesi ögrencilerine uygulama talebinin uygun olduğuna oylama sonucunda oy birliği ile;

Karar verildi 


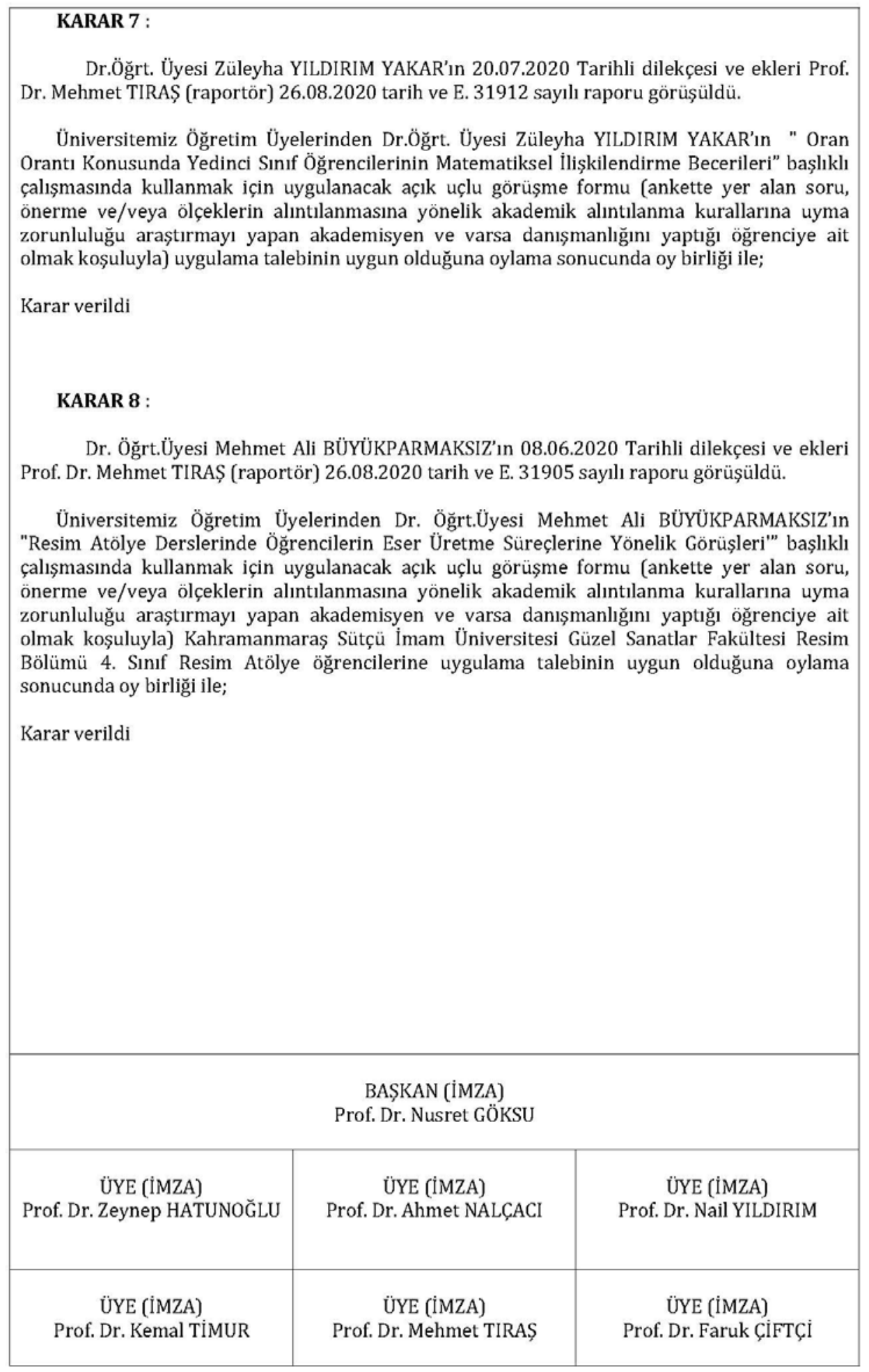

